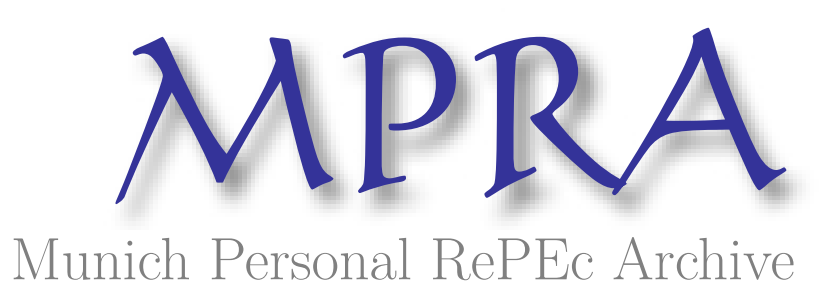

Mismatch: land reallocations, recovery

land rental and land rental market development in rural China

Che, Yi

10 August 2009

Online at https://mpra.ub.uni-muenchen.de/39794/

MPRA Paper No. 39794, posted 03 Jul 2012 12:52 UTC 


\title{
Mismatch: Land Reallocations, Recovery Land Rental and Land Rental Market Development in Rural China*
}

\author{
Yi Che \\ University of Hong Kong \\ This Draft: March 2012 \\ First Draft: August 2009
}

\begin{abstract}
Drawing upon a unique farm survey in 2003, I find that in rural China, Full-scale Land Reallocation (FLR) are more likely to follow egalitarian rule and Partial-scale Land Reallocation (PLR) take productivity of households into consideration. Econometric evidences shows two main results. First, FLR have positive effect on household land rental behavior, possibly because egalitarian FLR create a mismatch between household agricultural ability and land size and after FLR households has to participate in land rental market to adjust the mismatch. Second, PLR have negative effect on household land rental behavior which supports that land reallocation and land rental market are substitutes (Brandt, Rozelle and Turner, 2004).
\end{abstract}

Keywords: Mismatch; Egalitarian; Recovery Land Rental; Full-scale Land Reallocation; Partial-scale Land Reallocation

JEL Codes: Q15; Q13

*This paper is a revision of and updates my M.Phil. thesis "Land Rental Market Development in Rural China" in Division of Social Science, Hong Kong University of Science and Technology. I am particularly grateful to Ying Bai for his help and many suggestions on earlier drafts. I also thank Chicheng Ma, Nan Li, Huadong Song, Edward Jow-ching Tu, Satoru Shimokawa and participants of my M.Phil thesis defence seminar for their helpful comments, James Kai-sing Kung for making available the data set for analysis. I am alone responsible for any remaining errors. Corresponding author: Yi Che, tccheyi2005@hotmail.com. 


\section{Introduction}

"Households in a team are at different stages of their life cycles and thus have different labor endowments. They also have different levels of education, experience, and other abilities. As a consequence, the equal land-person ratio across households in a team generates a potential allocative inefficiency."

Yifu Lin (1988)

Development of land rental market is important for increasing farm output in developing countries, because it equalize marginal production among households which is the condition of maximal total agricultural output. Land rental market exhibit its salient role when the other two factor markets are distorted: land sales market would incur speculation and credit market is closely related to amount of land of villagers (Deininger and Feder, 2001). This is especially true in China. For example, there is no land sale market since farmers only enjoy land use right in rural China and formal credit available to farmers is scant due to the under developed local financial institutions.

In recent years, China has witnessed a emerging land rental market, shown in Figure 1. Yet, is there any factors retarding the development of a healthy land rental market in rural China. Conventional wisdom in the literature imply that since village leaders periodically reallocate land from low productive households to high productive ones, administrative land reallocation and land rental market are substitutes in rural China (Brandt, Rozelle and Turner, 2004). Therefore, land reallocation has negative effect on household land rental behavior. However, arable land is reallocated in two ways in rural China which is overlooked by previous studies investigating the effect of land reallocation on household land rental behavior: Full-scale Land Reallocation (FLR) and Partial-scale Land Reallocation (PLR). In the process of FLR, village leaders confiscate all the land of households and then distribute land equally among villagers. In the process of Partialscale Land Reallocation, village leaders only reallocate a part of one household's land to another household.

In this paper, I evaluate the relative impacts of FLR and PLR on household land rental behavior in rural China.

Drawing upon a unique data set surveyed by Development Research Centre (DRC) in 2003, I find evidences showing that FLR is more likely to follow egalitarian rule of land distribution and in the process of PLR village leaders reallocate land from low productive households to high productive ones.

A further detailed econometric analysis of a sample of 2102 households shows that, certeris paribus, households experienced more FLR are more likely to rent in or out land while households experienced more PLR are less likely to rent in land or out land. These results are robust to alternative model specifications and alternative measures of FLR and PLR. It also seems that our main results are not driven by outliers.

I attribute the positive effect of FLR on household land rental behavior to the fact that in the process of FLR, egalitarianism create a mismatch between household agricultural ability and land 
size, after FLR, households has to participate in land rental market to adjust this mismatch. Since land rental behavior induced of FLR is to recover household land to its previous size, I name it as Recovery Land Rental. In contrast, because the mismatch between agricultural ability and land size has been adjusted in the process of PLR, I observe that PLR has negative effect on household land rental behavior and PLR and land rental markets are substitutes (Brandt, Huang, Li and Rozelle, 2002; Brandt, Rozelle and Turner, 2004).

Egalitarian land distribution among farmers is ubiquitous in the world (Binswanger, Bourguignon and van den Brink, 2009) and farmers benefit (i.e., equity and efficiency) from the egalitarianism (Deininger and Jin, 2005). However, farmers are endowed with different farming abilities, egalitarian distribution of land create a mismatch between farmers' ability and land size. Although several scholars have noticed the nature of allocative inefficiency of egalitarian land distribution (Lin, 1988; Dong, 1996), quantitative evidence in the literature is scant. The contribution of our paper is that I provide a new interpretation of why egalitarian land reallocation have positive effect on household land rental behavior.

The rest of this article is organized as follows. In section 2, I introduce the background and literature on the topic of land rental in rural China. Section 3 is data, conjecture and stylized facts. Section 4 is a framework introducing why FLR and PLR would affect household land rental behavior. Econometric model used in the paper is provided in section 5. Section 6 is the empirical results as well as robustness checks. Section 7 is a simple welfare analysis of land rental market in rural China. Section 8 concludes.

\section{Background and Literature Review}

\subsection{Rural Farm Land System in China}

Communal arrangement of agricultural production in rural China failed because its rewarding system is too equal to create enough incentive for farming (Perkins, 1988). In order to overcome such a deficiency, the state introduces the Household Responsibility System (HRS) to rural between 1978 and 1984. Under HRS, village land is allocated to households on a per capita basis with a land contract between villagers and village leaders. After paying local taxes ${ }^{1}$ and meeting a mandatory transferring grain quota which involves delivering a certain amount of grain at a below-market price to the state procurement system, farmers can reap benefits from the land using. This kind of land institution has provided unexpected incentives to farmers for farming and caused unprecedented production growth in subsequent years (Lin, 1992). However, from the perspective of property rights, farmers only enjoy temporary land use right and land ownership is still in the hands of collectives (e.g., administrative village or natural village). So land cannot be sold under HRS system.

Fearing that insecure land tenure would dampen famers' working incentives, central government

\footnotetext{
${ }^{1}$ Agricultural tax has been progressively waived from 2002 to 2006 (Kennedy, 2007).
} 
extend the land contracting period from 15 years in 1984 to 30 years in 1993. And in Land Management Law (1998), Rural Land Contract Law (2003) and Property Law (2007), central government further emphasize that within land contracting period, land cannot be reallocated among households. However, influenced by communist ideology, survey evidence suggest that to adjust land distribution for population changes among the households (e.g., death, birth and daughter marriage), village leaders break up the initial contract and continuously reallocate land between households with population change to keep egalitarian distribution of arable land in the village (Liu, Carter, and Yao, 1998; Brandt, Huang, Li, and Rozelle, 2002; Kimura, Otsuka, Sonobe and Rozelle, 2011). For example, village leaders may reallocate land from a household with a member loss (e.g., death) to a household with a member addition (e.g., new baby).

The main actors in the process of land reallocation are village leaders, including party secretary, village head and accountant. Survey evidences shows that village leaders conduct land reallocation in two ways: Full-scale Land Reallocation (FLR) and Partial-scale Land Reallocation (PLR). FLR is conducted on a whole village basis: village leaders unscramble the current allocation of land in the whole village and then allocate land among villagers on a per capita basis. On the contrary, PLR is conducted on a case-by-case basis: village leaders only reallocate land of a small portion of households who need to do so (e.g., population change and efficiency consideration). For example, households who leave their land fallow or farm less intensively because of being short of farm labor will suffer from land confiscation and their land will be redistributed to other households who farm intensively (Rozelle and Li, 1998).

While land reallocation is only one way to transfer land among households, the other way of land transferring in rural China is through land rental market. In fact within the contracting periods, villagers has rights to rent their land to other households (Central NO.1 Notice, 1984). Land rental rights of villagers are further emphasized in Rural Land Contract Law (2003) and promoted in Central NO.1 Document (2010).

\subsection{Related Literature on Land Reallocation and Land Rental Market in China}

Brandt, Rozelle and Turner (2004) argues that since village leaders' chances of promotion and bonus are closely related to aggregate village farm output, they have incentives to reallocate land from low productive households to high productive ones through periodic land reallocation ${ }^{2}$. In contrast, the function of land rental market is also to transfer land from low intensive users to high intensive ones. Consequently, administrative land reallocation and land rental market are substitutes (i.e., Substitution Hypothesis) and land reallocation should have negative effect on household land rental behavior.

This view is supported in Deininger and Jin (2005). They find that households with high

\footnotetext{
${ }^{2}$ Several studies have shown that local economic performance is an important indicator for promotion of local leaders in China (Chen, Li and Zhou, 2005; Li, 2011; Xu, 2011).
} 
farming ability receive more land administratively and households with low farming ability are more likely to lose their land during the process of land reallocation ${ }^{3}$.

However, substitution hypothesis is not always supported by empirical evidence. For example, Yao (2000) and Kung (2002) find positive and significant effect of land reallocation on household land rental behavior. But existing literature lack a coherent explanation ${ }^{4}$ of why land reallocation has positive effect on household land rental behavior. This paper is an attempt to fill this gap.

\section{Data, Conjecture and Stylized Facts}

\subsection{Data and Variables}

The data set used in this study is obtained through a random multistage clustered farm survey conducted by the DRC in 2003. There are six provinces in the survey: Hunan in the south, Sichuan in the middle, Zhejiang, Fujian, Anhui in the south east, and Heilongjiang in the north east. In each province, 2 counties were randomly selected. In the next step, 8 villages were randomly selected from each selected county. At the village level, one of the main village cadres (i.e., village head, party secretary, or accountant) answered a questionnaire including detailed information regarding the criterion of land reallocation. Finally about 22 households were randomly selected from each village's registration book and then interviews were conducted both with household head and every member in the household. Household interview cover a broad range of information including number FLR and PLR experienced by the household since HRS, off-farm working activities, land rental market participation status, individual demographic characteristics, etc. After data cleaning, I finally have a valid sample of 2102 households from 95 villages. The geographical locations of the six provinces are shown in Figure 2.

One interesting pattern for FLR and PLR at village level in the data is that after the introduction of HRS, among the 89 villages $^{5}, 5$ villages did not conduct any land reallocation (No FLR and PLR); 25 villages conducted only FLR (Only FLR); 33 villages conducted only PLR (Only PLR); 26 villages conducted both FLR and PLR (Both FLR and PLR). There is also a large variation of frequency of FLR and PLR at province level: in Anhui province, 100 percent villages have conducted FLR and 60 percent villages have conducted PLR since HRS; in Fujian province, 87 percent villages conducted FLR while 14 percent villages conducted PLR since HRS; for the 16 villages in Heilongjiang province, 50 percent villages conducted FLR and 56 percent villages conducted PLR since HRS; in Hunan province, 43 percent villages conducted FLR and all the 16 villages conducted

\footnotetext{
${ }^{3}$ But Deininger and Jin (2005) also point out that administrative land reallocation is not as efficient as land rental market in improving farm production.

${ }^{4}$ Kung (2002) argue that because off-farm economy is developing so rapidly that mere land reallocation is insufficient to adjust household will of demand and supply of land. This explanation may not be quite appropriate because off-farm development has been holding constant in the household regression model.

${ }^{5}$ The original data includes 95 villages. We have no information for FLR in 4 villages and for PLR in 2 villages. In order to make the classification of No FLR and PLR, Only FLR, Only PLR and Both FLR and PLR, we lose 6 villages in the sample subsequently.
} 
PLR since HRS; in Sichuan province, 21 percent villages conducted FLR and all the 16 villages conducted PLR since HRS; in Zhejiang province, among all the 16 villages, 44 percent villages conducted FLR and 69 percent villages conducted PLR since HRS. Since village level or province level frequency of land reallocation may introduce measure error in the regression ${ }^{6}$, household level frequency of land reallocation is used in the analysis. For the total 2102 households in the sample, 295 households experienced no FLR and PLR, 1094 households experienced only FLR, 537 households experienced only PLR and 176 households experienced both FLR and PLR since HRS. Our key independent variables are number of FLR or PLR experienced by the household since HRS.

The dependent variable in the Probit model is a dummy indicating whether the household has rented in or out land. The dependent variable in the Tobit model is area of land the household has rented in or out.

Summary statistics of variables in the regression is provided in Table 1. Overall, all the variables have the expected range. The mean frequency of FLR and PLR at household are small, 1.44 and 0.7 respectively. The maximum frequency of FLR and PLR is 8 and 20 respectively. Percentage of households who have rented in or out land is $15 \%$ and $10 \%$ respectively. The mean area of land rented in or out is 1.43 and $0.23 \mathrm{mu}^{7}$.

Appendix Table A provides the definition of variables used in the paper and rationales of controls are introduced in the section of econometric model.

\subsection{Recovery Land Rental: Why FLR and PLR May Affect Household Land Rental Behavior?}

In terms of Substitution Hypothesis (Brandt, Rozelle, and Turner, 2004), there are actually two aspects that land reallocation would substitute the effect of land rental market. First, if some households have affluent arable land to farm and some households have no arable land to farm in the village, egalitarian land reallocation will alleviate land-labor mismatch (i.e., Substitution Effect One, SEO). Second, because of career concern of village leaders, they reallocate land from households with low farming ability to households with high farming ability to improve overall production in the village. In this sense, land reallocation also substitutes the effect of land rental market (i.e., Substitution Effect Two, SET). I argue that although egalitarian distribution of land significantly reduce land-labor mismatch, there still exist mismatch between farming ability and land size across individuals. Therefore, after egalitarian land reallocation, households are more likely to participate in land rental market to adjust the mismatch between farming ability and land size.

With respect to FLR and PLR in our paper, if FLR is more likely to follow egalitarian rule of land reallocation, then households experienced more FLR should have larger mismatch between

\footnotetext{
${ }^{6}$ If a villages conducts only PLR, some households which do not experience any PLRs may be assumed to be affected in the regression by using village level frequency of land reallocation.

${ }^{7}$ One $\mathrm{mu}$ is 0.0667 hectare.
} 
farming ability and land size ${ }^{8}$. Therefore households experienced more FLR are more likely to rent in or rent out land to adjust the mismatch. Here I name household land rental behavior because of mismatch created by egalitarian FLR as Recovery Land Rental, because households have to rely on land rental market to recover their land size to the original size because of FLR. If in the process of PLR, village leaders reallocate land from low intensive users to high intensive ones, there should be negative effect of PLR on household land rental behavior.

Can I find evidences showing the FLR is more likely to follow egalitarian rule in the data? I believe so. There are several pieces of evidence which imply FLR is more likely to follow egalitarian rule. First, among 57 villages conducting FLR in the past, 36 villages' village leaders report that the most important reason to conduct FLR is following command from higher level officials, 14 villages report that FLR is conducted because of population change, 2 villages report that FLR is conducted because of land occupation because of development of township enterprise. It seems that the most important reason for conducting FLR is command from upper level government. Since central government emphasize land egalitarianism in rural China, I expect that higher level official's command is more closely follow the egalitarian criterion of land reallocation. Therefore, after FLR, land is more equally distributed in the village. Second, according to answers of multiple choice question of procedures in conducting FLR in 57 villages, shown in table 2, I found that the process of FLR is very complex: 85.5 percent of villages organize a villagers' session, 72.7 percent of villages select villagers' deputy, 72.7 percent of villages will estimate the size of land ${ }^{9}, 74.6$ percent of villages do a lottery of land for very individual and 70.9 percent of villages would issuing a new land contract. In such a complex process of FLR, I expect that transparency and accountability is high. So if all villagers treasure the sparse asset (i.e., arable land), bargain powers ${ }^{10}$ owned by villagers should render FLR create an egalitarian distribution of land in the village. Third, I found that the gini coefficient for the 1094 households who experienced only FLR is 0.559 which is smaller than the gini coefficient 0.567 for these 537 households who experienced only PLR ${ }^{11}$. Although there are still confounding factors, statistically this 0.8 percent point difference suggests that FLR really create a more egalitarian distribution of land for households who experienced only FLR than households experienced only PLR. I can also dynamically look at the difference

\footnotetext{
${ }^{8}$ There are two points here. First, we assume that individual level mismatch will translate into household level mismatch between household farming ability and land size. We will elaborate this notion in the conceptual framework part. Second, mismatch between household farming ability and land size created by FLR is proportional to frequency of FLR in the household level. Robustness checks will be conducted for this assumption in the empirical part.

${ }^{9}$ Village leaders will first grade land according to its quality, so the pieces of land household received is quality adjusted (Lin, 1988; Liu, Carter and Yao, 1998).

${ }^{10}$ Actually, villagers have this kind of bargain power because all the villages in the sample have introduced Village Leader Election Institutions. Villagers can easily threat the village leaders not to vote them if they cannot obtain their "per capita land" in the village and previous studies have shown that this bargain process exists in rural China (Yao, 2004; Brandt, Rozelle, and Turner, 2004).

${ }^{11}$ We did not list the gini coefficients according to frequency of FLR and PLR, because we should, in some sense, "control" FLR when computing gini for PLR and "control" PLR when computing gini for FLR. Computing gini for households who experienced only FLR and for households who experienced only PLR maybe a possible way for such "control".
} 
of average gini coefficient of per capita arable land before and after the last FLR in the village. For the 57 villages conducted FLR, before the last time FLR, the average gini of per capita arable land is 0.21. However, after FLR the gini becomes 0.15 which suggests that after FLR land is more equally distributed in the village. Fourth, if mismatch between farming ability and land size in the household exists after FLR, I expect that willingness of changing current land holding should be different across households experienced FLR or PLR. Table 3 shows that the percentage of households who want to increase or decrease their land holding is highest $(60.45 \%)$ in villages only conducting FLR while it is lowest $(47.46 \%)$ in villages only conducting PLR ${ }^{12}$. And villages conducting both FLR and PLR stand in the middle (51.13\%). This evidence reflects that in the process of PLR, village leaders may reallocate land from "lazy" households to intensive households while FLR did not take household farming ability into account which is an inefficient way of land reallocation compared with PLR.

So is there any evidence showing that PLR is more efficient or "doing a better work" in the data? There are 2 points here. First, I assume that if village leaders care about their career and reallocate land from low productive households to high productive households (Brandt, Huang, Li and Rozelle, 2002; Brandt, Rozelle, and Turner, 2004), they will do it the mode of PLR. Because it is hard to imagine that household $A$ in a village becomes productive (i.e., grown up of children) and household $B$ becomes unproductive (i.e., aging), then village leaders in this village conduct FLR to initiate villagers' session, select villagers' deputy, estimate size of land, do a lottery and issue new land contract. The cost is too high if the aim is to reallocate some land from Household $B$ to household $A^{13}$. Therefore village leaders are more likely to conduct PLR if they want to reallocate land from low intensive households to high intensive ones. Third, I can show that there is a significant correlation between household farming productivity and PLR. After regressing ${ }^{14}$ frequency of PLR in the household on farm production, household head age, household head age square, per capita land, household education index, dependent ratio, female ratio and province dummies, I find that the coefficient of farm production is positive and significant at 1 percent level. This partially support that PLR is conducted depending on household productivity. These evidences may support the conjecture that "efficient" way of land reallocation take place mainly in the form of PLR.

From the facts of FLR and PLR listed above, I state our hypothesis as follows:

Hypothesis. Households experienced more FLR are more likely to participate in land rental market to adjust the mismatch created by egalitarian land reallocation between farming ability and

\footnotetext{
${ }^{12}$ We divided the sample into 4 groups: villages conducting no FLR and PLR, villages conducting only PLR, villages conducting both FLR and PLR and villages conducting only FLR.

${ }^{13}$ In FLR, suppose that the benefit $\Delta P=P_{A}-P_{B}$ is the production improvement by reallocating $\Delta A$ land from $A$ to $B$ where $P_{A}$ is production of household $A$ after FLR and $P_{B}$ is production of household $B$ after FLR. The cost is $T+n M$ where $T$ is time cost in organizing FLR in the village, and $M$ is production loss because of egalitarian distribution of land which is assumed to be constant across households and $n$ is number of households in the village. If $T+n M$ is much larger than $\Delta P$, village leaders would not conduct FLR and conducting PLR is highly possible.

${ }^{14}$ Full estimation results are available upon request. Farm production is value of agricultural output measured at market price.
} 
land size; households experienced with more PLR are less likely to participate in land rental market because PLR and land rental market are substitutes.

\subsection{A First Glance at Correlation}

Is there any descriptive correlation between land reallocation and household land rental behavior? Table 4 summarizes land reallocation and land rental facts across the six provinces. It seems that there is no clear correlation between land reallocation frequency and household land rental behavior. For example, Heilongjiang has the lowest land reallocation frequency (0.89), yet the percentage of household renting in land is neither the lowest or highest.

Since aggregate level measure of land reallocation and household land rental behavior may introduce measurement error, I resort to Figures 3 and 4 to examine the correlation between land reallocation and household land rental behavior. The horizontal line is number of FLR in Figure 3 and is number of PLR in Figure 4. The vertical line in Figures A, B, C and D are percentage of households rented in land, percentage of households rented out land, average size of land rented in and average size of land rented out.

Clearly our hypothesis is supported in Figures 3 and 4: there is a positive relationship between FLR and household land rental behavior and a negative association between PLR and household land rental behavior.

However, I do not know whether these associations are statistically significant. Neither do I know whether land reallocation picked up the effect of omitted factors. Therefore, I resort to the formal regression analysis in the next sections.

\section{Conceptual Framework}

In this section, I propose a conceptual framework to think about how and under what conditions FLR and PLR may affect household land rental behavior. Consider the equation

$$
a_{i}=X^{\prime} \beta+\varepsilon_{i}
$$

where $a_{i}$ is the farming ability of household $i$ and $X^{\prime}$ is a vector of variables determining household farming ability including female ratio, education level, number of labor, age structure and so on. I define the residual farming ability of the household as $\hat{\varepsilon_{i}}=a_{i}-X^{\prime} \beta$ where $\beta$ is estimated coefficients of $X^{\prime}$ in equation (1). Farming ability $\hat{\varepsilon}_{i}$ is different across individuals because of different personality and smartness among villagers ${ }^{15}$.

\footnotetext{
${ }^{15}$ Actually in labor economics, ability difference among students is a key to understand the outcome of education. Many scholars have try different methods to overcome this omitted factor in regression analysis: randomness in lottery (Angrist, 1990), instrumental variable method (Angrist, 1991) and identical twins (Zhang, Liu, and Yung, 2007).
} 


\subsection{Full-scale Land Reallocation: Mismatch and Tenure Insecurity}

\subsubsection{Autarchy Before FLR}

Suppose that the optimal land size for household $i$ corresponding to ability $\varepsilon_{i}$ is $A^{*}$ which is represented as vertical line $|\mathrm{AB}|$ in Figure 5. I first consider households who are in autarchy in the sense that these households own the optimal land size and do not need to participate in land rental market to adjust land holding. After FLR if the household land size is smaller than optimal land size, shown in Figure 5A, $|\mathrm{AB}|>|\mathrm{CD}|$, then these households ${ }^{16}$ would rent in land with size $|\mathrm{DE}|$ (i.e., Demand Recovery Land Rental). In contrast after FLR if household land size is larger than optimal land size, $|\mathrm{AB}|<|\mathrm{CD}|$ shown in Figure 5B, then these household, after FLR, would rent out land with size $|\mathrm{DE}|$ (i.e., Supply Recovery Land Rental).

In summary, unless all the households in autarchy has the same farming ability and household size and farming ability matched the land size after FLR optimally, then there is no positive effect of FLR on household land rental behavior. Otherwise, I should expect a positive effect of FLR on household land rental behavior for households in autarchy.

\subsubsection{Renting in Land Before FLR}

Now I look at what happened after FLR for households who initially want to rent in land after FLR. Figure 6A shows that after FLR, household land size decreases. $|\mathrm{AB}|$ is the optimal land size for the household with agricultural ability $\hat{\varepsilon}_{i},|\mathrm{BC}|$ is the land size in the household. After FLR, household land size becomes $|\mathrm{DE}|$. In order to adjust land size to agricultural ability, household

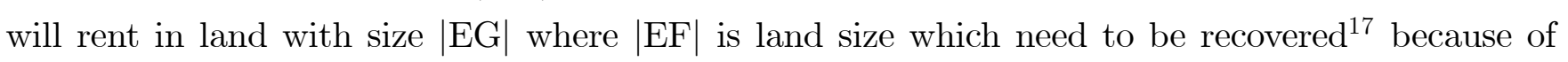
FLR and $|F G|$ is land size the household want to rent in without FLR.

Figure $6 \mathrm{~B}$ shows that after FLR, household land size increases. If the increase of land size $|\mathrm{EF}|$ after FLR just equals to the land size the household want to rent in $|\mathrm{AC}|$, then there is no land rental behavior for this household after FLR. As shown in Figure 6C, if the increase of land size $|\mathrm{EG}|$ after FLR is larger than $|\mathrm{AC}|$, the household will rent out land with size $|\mathrm{FG}|$. As before, I can call $|\mathrm{FG}|$ as Supply Recovery Land Rental. Figure 6D shows that if the increase of land $|\mathrm{EF}|$ after FLR is smaller than the land size the household want to rent in $|\mathrm{AC}|$, then the household would rent in land with size $|\mathrm{FG}|$. In Figure 6D, it seems that FLR is efficient because FLR decrease the mismatch between land size and agricultural ability.

\footnotetext{
${ }^{16}$ Unless under very strict conditions, individual level mismatch between land size and individual agricultural ability can translate into household level mismatch between household level farming ability and land size. For example, in a village where all the household only have two members. In a typical household of this village, matched land area of members' farm ability is $A$ and $B$. Here suppose $A>S$ and $B<S$ where $S$ is village per capital land size $\mathrm{S}$ distributed to household members. If $|A-S|=|B-S|$, then there is no mismatch between household farm ability and land size after egalitarian land reallocation. So we can see that this condition is too mechanical and very rare satisfied in the real world.

${ }^{17}$ Demand Recovery Land Rental.
} 
In sum, only in the case of Figure 6B, there is no effect of FLR on household land rental behavior. Otherwise, I expect a positive effect of FLR on household land rental behavior.

\subsubsection{Renting out Land Before FLR}

Now consider the case when the household want to rent out land before FLR. In Figure 7A, $|\mathrm{AB}|$ is the optimal land holding for the household and $|\mathrm{BC}|$ is the land size for this household. So the household want to rent out land with size $|\mathrm{AC}|$. If household land size increases to $|\mathrm{DF}|$ after FLR, then Supply Recovery Land Rental size is $|\mathrm{EF}|$.

After FLR, if the land size decreases to $|\mathrm{DE}|$ which is equals to $|\mathrm{AB}|$, shown in Figure $7 \mathrm{~B}$, then the household would not participate in land rental market.

Figure 7C shows that after FLR, land size decreases to $|\mathrm{DF}|$ which is smaller than $|\mathrm{AC}|$, then the household still need to rent out land with size $|\mathrm{EF}|$. FLR is efficient in this case.

Figure 7D shows that after FLR, land size decreases $|\mathrm{DE}|$, the household need to rent in land $|\mathrm{EF}|$ to match its farming ability (i.e., Demand Recovery Land Rental).

Only accidently in Figure 7B, FLR has no effect on household land rental behavior. Otherwise, there exists positive effect of FLR on household land rental behavior ${ }^{18}$.

\subsubsection{Tenure Insecurity}

Previous studies have found that land reallocation is a form of tenure insecurity to the household ${ }^{19}$ (Yang. 1997; Jacoby, Li, and Rozelle, 2002) and tenure insecurity has negative effect on household land rental behavior (Deininger and Jin, 2008; Noev, 2008; Kimura, Otsuka, Sonobe, and Rozelle, 2011). Following this kind of logic, FLR should have negative effect on household land rental behavior.

I can assume that the marginal effect of tenure insecurity for FLR on household land rental behavior is $\Delta \pi<0$. In contrast, suppose the marginal effect of mismatch for FLR on household land rental behavior is $\Delta \theta>0$.

Consequently, I may observe three possible outcomes concerning the effect of FLR on household land rental behavior empirically. If $|\Delta \pi|>|\Delta \theta|$, there exists negative effect of FLR on household land rental behavior. If $|\Delta \pi|<|\Delta \theta|$, the effect of FLR on household land rental behavior should be positive and I estimate a lower bound of the effect of mismatch on household land rental behavior. If $|\Delta \pi|=|\Delta \theta|$, there is no effect of FLR on household land rental behavior.

\footnotetext{
${ }^{18}$ In the paper, household land rental behavior means household land rental in both demand and supply side.

19 "The more times that land was reallocated in a village, the more likely that a farmer would lose a particular plot of land. Insecurity was exacerbated if the dates of a village-wide adjustment were not known in advance" in Brandt, Huang, Li and Rozelle (2002).
} 


\subsection{Partial-scale Land Reallocation: Substitution Hypothesis}

Since the main motivation of land reallocation is population change, land should be equally distributed in rural ${ }^{20}$. So I expect that if substitution effect exist, it should be SET. As conjectured before, if village leaders intend to increase agricultural production through reallocating land, they mainly do this in the form of PLR. Consequently, I expect that the effect of PLR on household land rental behavior is negative.

Graphically speaking, I can refer to Figure 8. Suppose that line $|\mathrm{AB}|$ is the land holding of household $X$ and line $|\mathrm{DF}|$ is the land holding of household $Y$. Yet, the optimal land holding for household $X$ is $|\mathrm{BC}|$ and the optimal land holding for household $Y$ is $|\mathrm{DE}|$, according to household level agricultural ability. If after PLR where village leaders reallocate some land from household $Y$ to household $X$, household $X$ 's land holding becomes $|\mathrm{GI}|$ and household $Y$ 's land holding becomes $|\mathrm{JK}|$. If $|\mathrm{HI}|=|\mathrm{KL}|^{21}$, then both household $X$ and household $Y$ do not need to participate in land rental market to adjust their land holding. If $|\mathrm{HI}|>|\mathrm{KL}|$, then household $X$ still need to rent in land with size $|\mathrm{HI}|-|\mathrm{KL}|$ which is smaller than the land area $X$ supposing to rent in $|\mathrm{AC}|$ before PLR and household $Y$ do not need to participate in land rental market. If $|\mathrm{HI}|<|\mathrm{KL}|$, then household $Y$ still need to rent out land with size $|\mathrm{KL}|-|\mathrm{HI}|$ which is also smaller than land area $Y$ supposing to rent out $|\mathrm{EF}|$ before PLR and household $X$ do not need to participate in land rental market this time.

In all these cases, I should expect that there is a negative effect of $\mathrm{PLR}^{22}$ on household land rental behavior.

\section{$5 \quad$ Econometric Model}

A basic form of equation to be estimated is as follows:

$$
\begin{gathered}
\operatorname{Pr}\left(R_{i p}^{\text {in }}=1 \mid X\right)=F\left(\beta_{0}^{\text {in }}+\beta_{1}^{\text {in }} f l r_{i p}+\beta_{2}^{\text {in }} p l r_{i p}+H^{\prime} \beta_{3}^{\text {in }}+V^{\prime} \beta_{4}^{\text {in }}+\delta_{p}^{\text {in }}\right) \\
\operatorname{Pr}\left(R_{i p}^{\text {out }}=1 \mid X\right)=F\left(\beta_{0}^{\text {out }}+\beta_{1}^{\text {out }} f l r_{i p}+\beta_{2}^{\text {out }} p l r_{i p}+H^{\prime} \beta_{3}^{\text {out }}+V^{\prime} \beta_{4}^{\text {out }}+\delta_{p}^{\text {out }}\right)
\end{gathered}
$$

where equation 2 is the Probit model ${ }^{23}$ in the demand side and equation 3 is the Probit model

\footnotetext{
${ }^{20}$ Even for PLR, this is also true. For example, among all the 63 villages conducting PLR, in 49 villages, village leaders only reallocate land of households who have population change in the process of PLR. Before the last time PLR, the average gini in all villages is 0.22 and after PLR, the average gini is 0.17 .

${ }^{21}$ Here $|\mathrm{HI}|=|\mathrm{AC}|$ and $|\mathrm{KL}|=|\mathrm{EF}|$.

${ }^{22}$ There are two ways for village leaders to conduct PLR. First, they may reallocate some land from an unproductive household to a productive household. Second, they may reallocate some land from village flexible land (i.e., Jidongtian) to a productive household. In both cases, households received more PLR are less likely to participate in land rental market to adjust their land holding because PLR has adjust their land holding according to their farming ability.

${ }^{23}$ Because our dependent variable is a dummy, to suppress the predicted probability between zero and one, we choose Probit model. In the section of empirical results, we also experiment with other dummy dependent variable models as a robustness check.
} 
in the supply side. $F($.$) denotes the standard normal cumulative distribution function. R_{i p}^{i n}$ is a dummy indicating whether household $i$ in province $p$ has rented in land and $R_{i p}^{\text {out }}$ is also a dummy denoting whether household $i$ in province $p$ has rented out land. $\beta_{0}$ is a constant. flr $r_{i p}$ is the frequency of FLR experienced by $i, p l r_{i p}$ is the frequency of PLR experienced by $i$. The coefficients of interest throughout the paper is $\beta_{1}^{\text {in }}, \beta_{1}^{\text {out }}, \beta_{2}^{\text {in }}$ and $\beta_{2}^{\text {out }}$ (i.e., the effects of FLR and PLR on household land rental behavior). If the effect of mismatch on household land rental is larger than the effect of tenure security for FLR, I expect $\beta_{1}^{\text {in }}>0$ and $\beta_{1}^{\text {out }}>0^{24}$; if SET exists in the process of PLR, I expect that $\beta_{2}^{\text {in }}<0$ and $\beta_{2}^{\text {out }}<0^{25}$. In order to control for factors which are common within the province and affect household land rental behavior, province fixed effects $\delta_{p}$ (i.e., province dummies) are included in equations (2) and (3).

In order to alleviate omitted variable bias, I included a vector of household characteristics found to be important for household land rental behavior, $H^{\prime}$. Per capita arable land is included because I expect that households with more arable land are more likely to rent out land and less likely to rent in land (Lin, 1995) ${ }^{26}$. Household head age and head age square are also included in $H^{\prime}$. Household head is the major labor force in the household, so his or her age may reflect the overall household life cycle $^{27}$. I also include cadre household dummy because cadre household may enjoy various off-farm opportunities or gray incomes, so cadre household may not need to farm for a living. Therefore I expect that cadre households are less likely to participate in land rental market (Zhang, Ma and Xu, 2004). Household head education level is also included (i.e., illiteracy, primary school, junior high school, high school, college, university or higher). Higher education may represent higher farming management ability which will incur such households to rent in land and not to rent out land. Following Jin and Deininger (2009), I also include household labor age structure (i.e., household population whose age is less than 16 years old, household population whose age is between 16 and 60 , household population whose age is larger than 60 years old. Moreover, female ratio in the

\footnotetext{
${ }^{24}$ Actually, if FLR provides egalitarian distribution of land in the village, there should be SEO in the process of FLR (i.e., FLR equalize land-labor ratio in the village and thus reduce landless in the village). However, if we still estimate a positive effect of FLR on household land rental, that means the mismatch effect of FLR is larger enough to overcome the negative effect of tenure insecurity and the negative effect of SEO. We omit the detail discussion of SEO in the paper, because as early as 1980s, land-labor ratio in rural China is very equal (Lin, 1988). So SEO, if exist, maybe quite small in reality. Moreover, in both the conceptual framework and econometric model, per capita arable land is always controlled for in the sense that we are comparing households with more FLR to households with less FLR at the same level of land-labor ratio, so SEO is effectively controlled for in our case.

${ }^{25}$ Kung and Bai (2011) show that tenure created by FLR is more insecure than tenure created by PLR because farmers cannot keep the same plots after FLR and PLR is predictable. However, even if PLR also created tenure insecurity and $\beta_{2}^{\text {in }}<0$ and $\beta_{2}^{\text {out }}<0, \beta_{2}^{\text {in }}$ and $\beta_{2}^{\text {out }}$ are the combined negative effects of SET and tenure insecurity. Moreover, one may argue that because the main motivation of PLR is population change, PLR also created egalitarian distribution of land in the village. Yet if $\beta_{2}^{\text {in }}$ and $\beta_{2}^{\text {out }}$ are still negative, $\beta_{2}^{\text {in }}$ and $\beta_{2}^{\text {out }}$ are the combined negative effects of SET and tenure insecurity plus the positive effect of mismatch created by PLR. To make the discussion simple, we omit the tenure insecurity and mismatch created by PLR.

${ }^{26}$ Actually, Deinigner and Jin (2005) find that land rental market contribute to equity goal in the village (i.e., there is negative effect of per capita arable land on household land rental behavior).

${ }^{27}$ In agricultural sector age is an important indicator for farming experience, so higher age of the household head may induce more land to rent in and less land to rent out (Vranken and Swinnen, 2006; Neov, 2008). However, very old farmers suffer from physical constraint of farming, so we include the square to capture the life cycle effect of age.
} 
household is also included. Households with more labors between age 16 and $60^{28}$ or with more male $^{29}$ should be more likely to rent in land and less likely to rent out land. I also control for share of off-farm workers in the household. It is hypothesized that households with more members participating in off-farm work is more likely to rent out land ${ }^{30}$ and less likely to rent in land (Lin, 1988; Deininger and Jin, 2005). Agricultural $\operatorname{tax}^{31}$ is also included in the regression model. Since it is the custom for out-renters to transfer agricultural taxes to in-renters in rural China (Lohmar, Zhang and Somwaru, 2001), high agricultural tax may induce transaction cost for land renting (Coase, 1937, 1960) and thus will suppress land rental on both demand and supply side ${ }^{32}$. I also include nonfarm asset of the household in the regression. Nonfarm assets include value of houses, transportation instruments, small business assets and so on. The higher value of nonfarm asset, the more likely the household will rent out their land, because they can easily diversify their income if they want (Deininger and Jin, 2005). Number of hog and cattle in the household, representing farm assets, are also contained in the regression. Hogs can provide fertilizer for farming while cattle are important farm draft power (Rozenzweig and Wolpin, 1993), so they should have positive effects on household land rental behavior in demand side and negative effects on household land rental behavior in supply side.

$V^{\prime}$ is a vector of village control variables. Distance of the village to county centre is included to capture off-farm work opportunities. The nearer of the village to county centre, the more off-farm work opportunities and consequently households in these villages are more likely to rent out land and less likely to rent in land (Lin, 1988). Following the literature (Deininger and Jin, 2005; Jin and Deininger, 2009), I also included a dummy indicating whether household who want to rent in or out land need village leaders' sanction because this can be considered as a sort of transaction $\operatorname{cost}^{33}$. Land rental market should be inactive in these villages where sanction of land rental is needed. In the end, the average cash rent in the village is included as the last village control variable ${ }^{34}$. Higher rent represents higher transaction cost of land rental and thus will induce less household renting in land. In contrast, higher rent means more profits for out-renters, so higher rent should

\footnotetext{
${ }^{28}$ People's prime age for working.

${ }^{29}$ In terms of physical work, male should be more productive than female. In our case, farming is by and large physical work.

${ }^{30}$ The reason is that if many members in the household participate in off-farm work, there should be less available labor for farming. So these households are more likely to rent out the unfarmed land or under farmed land for rent.

${ }^{31}$ Although agricultural tax start to cancel in year 2000, at the time of our survey in 2003, there are many places exerting agricultural tax to farm households.

${ }^{32}$ Actually, owning more land will incur cash-unavailable grain quota task and thus can also insert transaction cost for land rental (Lohmar, Zhang and Somwaru, 2001). Yet no more than 5\% of households in the sample still hold grain quota and the variable of grain quota is not significant in the regression, so we drop this variable in the analysis.

${ }^{33}$ Central NO.1 Notice (1984) specify that households who want to rent in or out land need the sanction of village leaders. However, in Rural Land Contract Law (2003), this restriction is removed.

${ }^{34}$ There are three ways in which rent was paid in our sample: paying a certain amount of output; paying cash rent; nothing. The reason why there exists zero rent is that if out-renters leave their land fallow, village leader may reallocate their land in the next round of land reallocation (Yang, 1997; Kimura, Otsuka, Sonobe and Rozelle, 2011). So in order to keep use rights of land, households being lack of farm labor will rent out their land and charge nothing. There are only six households who employ sharecropping (average rent is $20 \%$ of production) as the method to pay rent, so there should be little incentive issue in our sample (Otsuka, Chuma and Hayami, 1992).
} 
have positive effect on household land rental on supply side ${ }^{35}$.

By replacing $R$ with a continuous variable $A$ indicating area rented in or out, I can estimate similar equations of (2) and (3). Because of the obvious left censoring problem (i.e., $85 \%$ households did not rent in land and $90 \%$ households did not rent out land) of $A$, I use Tobit model to avoid negative predicted rental area after regression (Tobin, 1958). Maximum Likelihood Estimation method would be used to derive the coefficients of our interest.

\section{Empirical Results}

\subsection{Main Results}

\subsubsection{Demand Side Results}

This section presents our main results. Table 5 reports estimation results in the demand side while Table 6 is the estimation results in the supply side. All standard errors in the paper are White's standard errors which are totally robust against arbitrary heteroskedasticity and clustered at province level ${ }^{36}$ (Hayashi, 2000).

Columns 1 to 3 in Table 5 report Probit model estimation results of household land rental behavior in the demand side. In column 1, I find that the effect of FLR on whether household would rent in land is positive and highly significant, 0.083 with a standard error of 0.02 . The more FLR the household experienced in the past, the more likely they will rent in land. This suggests that the effect of mismatch between agricultural ability and land size created by FLR on household land rental dominates the effect of tenure insecurity on household land rental. In contrast, there exist a negative and statistically significant effect of PLR on whether household would rent in land, -0.065 with a standard error of 0.029. It implies that SET works where PLR substitute the effect of land rental market (Brandt, Rozelle, and Turner, 2004). Column 2 of Table 5 is results where household controls and village level controls are added and column 3 of Table 5 further adds province fixed effects. It seems that the addition of these control variables does not affect our baseline findings.

Columns 4 to 6 of Table 5 provide the estimation results of Tobit model in demand side. Column 4 of Table 5 are the effect of FLR and PLR on area of land rented in and columns 5 and 6 further add covariates and province fixed effects respectively. In all cases, there is a positive effect of FLR on area rented in, 2.114 with a standard error of 0.674 and a negative effect of PLR on area rented in, -1.323 with standard error of 0.658 in column 6 of Table 5.

Although with a number of controls, the explanatory power of the Probit and Tobit are not

\footnotetext{
${ }^{35}$ We take village rent as the average cash rent per mu in the village, thus our measure of rent is crude. Moreover, rent and the area of rented in or out may be determined simultaneously. For example, households who want to rent in large area of land usually have higher farming ability, so out-renters in this case obtain higher bargain power and the rent increases accordingly (e.g., equilibrium result). So our estimation result for rent should be interpreted with caution.

${ }^{36}$ We assume households are independent across provinces but can be serial correlated within province.
} 
large. The pseudo R-square in column 3 and 6 are 0.11 and 0.06 respectively. However, if I set the fitted value to one if it is larger than half unit and zero otherwise, the correctly predicted values in columns 3 is $85 \%$ which is pretty high.

Overall, the message I get from estimation results in demand side is very clear: the more FLR experienced by the household in the past, the more severe the mismatch is between household farming ability and land size (i.e., allocation inefficiency), thus those households are more likely to adjust their land holdings through land rental market. Meanwhile, the effect of mismatch created by FLR is large enough to overcome the negative effect of tenure insecurity.

In contrast, efficient land reallocation is more likely to be conducted in small scale (i.e., PLR). For instance, if some households in the village farm less intensively, I expect that village leaders only reallocate the land of those households to other households who farm intensively (Rozelle and Li, 1998). It appears that PLR reflects the farming ability and willingness to farm across households and thus substitutes the effect of land rental market.

Do our estimates make quantitative sense? One more FLR experienced by the household, holding mean values of other controls, increase the probability that the household will rent in land by 2.1 percent point. Note that this 2.1 percentage point is a lower bound of the effect of mismatch on household land rental. For PLR, one more PLR experienced by the household, at the mean value of other covariates, decrease the probability that the household will rent in land by 1.5 percent point which is 0.6 percent point lower than the effect of FLR. In terms of land rental area, one more FLR experienced by the household would expand the area rented in by $2.1 \mathrm{mu}$ while one more PLR experienced by the household decrease the area rented in by $1.3 \mathrm{mu}$. For a household with median productivity in our data, this additional $2.1 \mathrm{mu}$ would translate into 1514 yuan increase of production from initial 2883 yuan.

All the other covariates are by and large in the expected sign. Although in a marginal significant level, aged household head are more likely to rent in land and very old household head will not do so $^{37}$. Interestingly, households with more per capita land are more likely to rent in land. This may because household with more arable land intend to obtain scale economy of farming, mostly contributed by the development of advanced farm technology. Households with more "consumers" (i.e., old members and females) are less likely to rent in land because of labor constraint. And cadre household seems have no effect on household land rental behavior. Consistent with previous findings, households with more members participating in off-farm work are less likely to rent in land or rent in land in small areas. Similarly, the negative coefficients of household education and nonfarm asset suggest that educated households and households with more nonfarm assets can easily diversify their income source and thus are less likely to rent in land. Households with more hogs which may provide more land fertilizer are more likely to rent in land and it seems that cattle power does not help much for farming. Households in villages near county centre would benefit more from off-farm market development and thus are less likely to rent in land or rent in land in

\footnotetext{
${ }^{37}$ The turning point is about 42 years old. This may because of the life cycle constraint.
} 
small areas. Both land rental sanction and rent appears not to be a source of transaction cost for household who want to rent in land.

\subsubsection{Why FLR and PLR Have No Effect on Household Land Rental Behavior in Supply Side}

Table 6 reports the main results on the supply side ${ }^{38}$. Unexpectedly, coefficients of FLR and PLR are both insignificant in columns 3 and 6 (i.e., the full model for Probit and Tobit) ${ }^{39}$. How to interpret that? A simple and quick guess is that households who rent out land are mostly migrant households. When the surveyor come to households who rent out land, all the family members have already settle in the urban area, working and living. So our raw data under report households in the supply side which is common in rural household survey (Lohmar, Zhang and Somwaru, 2001). This is possible since in our sample, $15 \%$ households rented in land and and $10 \%$ households rented out land, but the area rented in per household is about six times larger than the area rented out (1.43 $\mathrm{mu}$ versus $0.23 \mathrm{mu}$ ). Combined with the fact that few villagers rented in or out their land from or to people outside the village (Che, 2009), there must be many under reported households in the supply side. Consequently, missing values in the supply side of land rental market render our estimates not precise.

However, the above explanation cannot provide the mechanism why sample truncation in supply side would cause the effect of FLR and PLR on household land rental behavior insignificant. I favor another explanation here. Total income of households who rent out land in our sample is 39417 yuan while the total income of households who rent in land is 22015 yuan. This large income difference is largely driven by off-farm incomes, 18746 yuan for out-rentees and 6396 yuan for in-rentees, though farm income adjusted off-farm income difference a little bit, 1394 yuan for out-rentees and 9634 yuan for in-rentees ${ }^{40}$. Combined with fact that households in the demand side have high incentive to farm for living, this evidence of income difference may suggest that households in the supply side are not sensitive to the benefit they get from land renting while in-rentees are very sensitive to the benefit of land rental. In other words, the utility function faced by in-rentees and out-rentees are different. This is especially true if the rent is low. For example, in our sample, the rent is only 79 yuan per mu for one year ${ }^{41}$. At the same time, to rent out land, out-rentees have to "advertise" the information that they want to rent out land, negotiate with the other party about terms in the contract, sign contract, collect rent and so on. At the same time, out-rentees may want to enjoy leisure rather than rent out their land in this case, especially the benefit is low.

How to link these facts to the insignificant effect of FLR and PLR on household land rental

\footnotetext{
${ }^{38}$ All the covariates are largely the mirror of demand sides. To save space, we do not interpret the coefficients of covariates explicitly.

${ }^{39}$ One point here is that Probit and Tobit model fits the data better in the supply side than in the demand side reflected by the increased pseudo R-square in columns 3 and 6 of table $6,0.27$ and 0.14 respectively. It seems that our models in the supply side have larger prediction capability than in demand side.

${ }^{40}$ In this paper, we use in-rentor or in-rentee to represent households who rented in land and out-rentor or outrentee to denote households who rented out land.

${ }^{41}$ Average rent for in-rentees is 326 yuan per arable land in our sample.
} 
behavior? Suppose that the rent for both in-rentees and out-rentees is $r, T$ is the time needed to rent in land or rent out land, the transaction cost of land renal is $c$ for both parties and $p$ is the production of rented land for in-rentees. In case of FLR, after FLR, if household $i$ have area of land $\Delta A$ to provide in the land rental market compared to its optimal land holding $A^{*}$, the utility household $i$ get from land rental $U_{\text {out }}(r-c)$ is smaller than the utility get by enjoying leisure time $U_{\text {out }}(T)$. This is possible because $r$ is low and $c$ is high in the village (Zhang, Ma and Xu, 2004; Deininger and Jin, 2005). So household $i$ would not participate in land rental market although mismatch exists. If after FLR household $i$ want to rent in land, the utility $i$ get by renting in land is $U_{i n}(p-r-c)$ and the utility $i$ get by enjoying leisure is $U_{i n}(T)$. Because it is reasonable to assume that $p$ is large for households who want to rent in land, I expect $U_{i n}(p-r-c)>U_{\text {in }}(T)$ and thus $i$ would participate in land rental market. Overall, I observe significant effect of FLR on household land rental behavior in demand side but not in supply side. By the same token, households who initially want to rent in land obtain land after PLR (i.e., their residual ability of farming is satisfied by the additional land provided by PLR), so I observe negative effect of PLR on household land rental in demand side. However, although in the process of PLR village leaders confiscate a part of land from households who initially want to rent out land, they enjoy other sources of income and have no interest for farming even using the remaining land. So they may further participate in land rental market in supply side. In this case, I cannot observe negative effect of PLR on household land rental behavior in supply side (i.e., households in supply side are not sensitive to farming).

\subsection{Robustness Checks}

In this section, I perform a number of robustness checks for our main results.

Alternative Dummy Dependent Variable Models: in probit model, I assume that the error term follows standard normal distribution. To check whether this assumption are driving our baseline results, I provide results using other alternative dummy dependent variable models: linear probability model assuming error term asymptotically follows $t$ distribution, logit model assuming error term follows logistic distribution and semi-parametric model not assuming any distribution of the error term (Gallant and Nychka, 1987). Estimation results are shown in Table 7. Basically, our benchmark results of the effects of FLR and PLR on household land rental behavior are not affected: there is positive effect of FLR and negative effect of PLR on household land rental behavior on demand side while there is no effect of FLR and PLR on household land rental behavior on supply side.

Subsample Analysis: in heilongjiang province, the average per household arable land is 22.1 $\mathrm{mu}$ which is much higher than other provinces $3.6 \mathrm{mu}$. In contrast, within zhejiang province, average share of off-farm workers in the household is 0.39 while the average share of off-farm workers in other provinces is just 0.23 . In order to assure that households in these two provinces are not "outliers", I omit observations in heilongjiang and zhejiang separately in Table 8. Again, our estimates of FLR and PLR on household land rental behavior are unaffected. 
Alternative Measures of FLR and PLR: Tables 9 and 10 provide results using two alternative measures of FLR and PLR. In table 9, I use a dummy indicating whether the latest land reallocation is FLR or PLR. Because I cannot estimate the effect of latest land reallocation being FLR on household land rental behavior while controlling for the latest land reallocation being PLR, I include dummy whether the latest land reallocation is FLR or PLR separately. By and large, our main results preserved. The mismatch effect created by FLR is significant now in both demand and supply side. It seems that PLR, this time, only affects extensive margin of land rental in demand side and does not affect extensive margin of land rental in demand side. Again, PLR does not affect households who intend to rent out land. In Table 10, I use a dummy indicating whether the household only experienced FLR or PLR as alternative measures for FLR and PLR. The same as before, to alleviate multicollinearity problem, I included FLR and PLR separately. The results from Table 10 indicates that they have little effect of our main results and the mismatch effect created by FLR spreads to the supply side again.

\section{$7 \quad$ Welfare Analysis}

\subsection{Efficiency Gain of Land Rental Market: Are In-rentee Households More productive?}

An intriguing question after our analysis above is that are in-rentee households more productive than out-rentee households or households in autarky? Following Lohmar, Zhang and Somwaru (2001), I provide a speculative estimation of efficiency gain of land rental market in rural China.

Consider Cobb-Douglas household agricultural production function $Q_{i}=A L_{i}^{\alpha} K_{i}^{\beta}$, where $Q$ if value of farm production calculated at market price (Benjamin and Brandt, 2002), $A$ is solow residual and $L$ is farm labor and $K$ is area of operational land. Taking log of this function and augment it with share of off-farm members, land quality, fertilizer investment, number of hogs, number of cattle and in-rentee household dummy which is our interest, I can get the estimation equation as follows:

$$
\begin{aligned}
\ln Q_{i}= & \ln A_{i}+\text { rrentin }_{i}+\alpha \ln L_{i}+\beta \ln K_{i}+\theta_{1} \text { off }_{i}+\theta_{2} \text { quality }_{i} \\
& +\theta_{3} \text { fertilizer }_{i}+\theta_{4} \text { hog }_{i}+\theta_{5} \text { cattl }_{i}+\pi_{p}+\varepsilon_{i}
\end{aligned}
$$

where $\pi_{p}$ is province fixed effects and $\varepsilon_{i}$ is the error term. Table 11 presents estimates of equation (4). Column 1 of Table 11 is result only including renting in land household dummy as independent variable, column 2 of Table 11 further includes household controls and column 3 of Table 11 add province fixed effects. In all cases, $\gamma$ is positive and highly significant, 1.186 with a standard error of 0.247 in column 3 . It indicates that, holding other controls constant, households 
who rent in land produce $118.6 \%$ more than other households ${ }^{42}$. Now consider Taohua village in Hunan province which has the median number of households in our sample 436, the median production of households in the village is 1708 yuan and percentage of households who rented in land is $23.8 \%$. According to our estimates of equation (4), land rental market development increases farm production in Taohua village by 210672 yuan. Note that farm cost is not excluded here. This correction of land misallocation is not trivial given the fact that annual average household farm income is only 941 yuan.

\section{Conclusion}

Although according to laws in China, land reallocation is prohibited to preserve land tenure security. However, survey evidences indicate that by ignoring these related laws, village leaders reallocate land periodically to adjust household population change (Kimura, Otsuka, Sonobe and Rozelle, 2011). Interestingly, village leaders reallocate land in two ways (i.e., FLR and PLR). In the process of FLR, village leaders first confiscate all the land in the households and then distribute the land equally among villagers. Villagers usually cannot keep the same plot of land after FLR. In the process of PLR, village leaders only reallocate a portion of land from one household to another who need to do so. By using a data set surveyed by DRC in 2003, this paper shows that FLR are more likely to follow egalitarian rule of land distribution and PLR takes into account of households' agricultural productivity.

I then evaluates the relative effects of FLR and PLR on household land rental behavior in rural China. Econometric evidences suggest that households experienced more FLR are more likely to participate in land rental market to adjust the mismatch between farming ability and land size created by egalitarian FLR while households experienced more PLR are less likely to participate in land rental market supporting that PLR and land rental market are substitutes (Brand, Roselle and Turner, 2004). Empirical results also indicate that land rental market has a large positive impact on total farm production in the village.

The caveat of the paper is that FLR and PLR may be endogenous in the process of household land rental behavior. For example, it is possible that FLR and PLR are measured with error, village leaders reallocate land based on household land rental participation status (i.e., reverse causality) and some household omitted variables correlated both FLR, PLR and household land rental behavior. Although I can argue that land reallocation to households is a top-down process which can be exogenous, this paper need separable instruments for FLR and PLR econometrically. I consider finding convincible instruments or possible experimental methods as future work.

\footnotetext{
${ }^{42}$ It seems that land quality, off farm labor share and number of hogs in the households are important determinants of farm production while farm labor, land quality and fertilizer investment and number of cattle in the household are not that important household farm production function.
} 


\section{References}

[1] Acemoglu, Daron and Simon Johnson. (2005): "Unbundling Institutions," Journal of Political Economy, 113(5): 949-995.

[2] Acemoglu, Daron, Simon Johnson, and Todd Mitton. (2009): "Determinants of Vertical Integration: Financial Development and Contracting Costs," Journal of Finance, 64(3): 1251-1290.

[3] Acemoglu, Daron, Tarek A. Hassan, and James A. Robinson. (2011): "Social Structure and Development: A Legacy of the Holocaust in Russia," Quarterly Journal of Economics, 126: 895-946.

[4] Angrist, Joshua D. (1990): "Lifetime Earnings and the Vietnam Era Draft Lottery: Evidence from Social Security Administrative Records," American Economic Review, 80(3): 313-336.

[5] Angrist, Joshua D. (1991): "Does Compulsory School Attendance Affect Schooling and Earnings?" Quarterly Journal of Economics, 106(4): 979-1014.

[6] Benjamin, Dwayne and Loren Brandt. (2002): "Property Rights, Labour Markets, and Efficiency in A Transition Economy: The Case of China," Canadian Journal of Economics, 35(4): 689-716.

[7] Binswanger, Hans P., Camille Bourguignon, and Rogier van den Brink. (2009): "Agricultural Land Redistribution: Toward Greater Consensus". The World Bank: Washinton, D.C.

[8] Brandt, Loren, Scott Rozelle, and Matthew A. Turner. (2004): "Local Government Behavior and Property Right Formation in Rural China," Journal of Institutional and Theoretical Economics, 160, 627-662.

[9] Brandt, Loren, Jikun Huang, Guo Li, and Scott Rozelle. (2002): "Land Rights in Rural China: Facts, Fictions and Issues," China Journal, 47: 67-97.

[10] Coase, H. Ronald. (1937): “The Nature of the Firm," Economica, 4, 386-405.

[11] Coase, H. Ronald. (1960): "The Problem of Social Cost," Journal of Law and Economics, 3, $1-44$.

[12] Che, Yi. (2009): "Land Rental Market Development in Rural China," Thesis (M.Phil., Division of Social Science), Hong Kong University of Science and Technology.

[13] Chen, Ye, Hongbin Li, and Li-an Zhou. (2005). "Relative Performance Evaluation and the Turnover of Provincial Leaders in China." Economics Letters, 88(3): 421-425.

[14] Deiniger, Klaus and Gershon Feder. (2001): "Land Institutions and Land Markets," in Bruce L. Gardner and Gordon C. Rausser, Handbook of Agricultural Economics, 1: 288-331. 
[15] Deiniger, Klaus and Songqing Jin. (2005): "The Potential of Land Rental Markets in the Process of Economic Development: Evidence from China," Journal of Development Economics, 78, 241-270.

[16] Deiniger, Klaus and Songqing Jin. (2008): "Land Sales and Rental Markets in Transition: Evidence from Rural Vietnam," Oxford Bulletin of Economics and Statistics, 70, 67-101.

[17] Dong, Xiao-yuan. (1996): "Two-tier Land Tenure System and Sustained Economic Growth," World Development, 24(5): 915-928.

[18] Gallant, A. Roland and Douglas W. Nychka. (1987): "Semi-nonparametric Maximum Likelihood Estimation," Econometrica, 15: 363-390.

[19] Jacoby, Hanan G., Guo Li, and Scott Rozelle. (2002): "Hazards of Expropriation: Tenure Insecurity and Investment in Rural China," American Economic Review, 92(5): 1420-1447.

[20] Jin, Songqing and Klaus Deininger. (2009): "Land Rental markets in the Process of Rural Structural Transformation," Journal of Comparative Economics, 37(4): 629-646.

[21] Kennedy, John James. (2007): "From the Tax-for-Fee Reform to the Abolition of Agricultural Taxes: The Impact on Township Governments in North-west China," China Quarterly, 189: 43-59.

[22] Kimura, Shingo, Keijiro Otsuka, Tetsushi Sonobe, and Scott Rozelle. (2011): "Efficiency of Land Allocation through Tenancy Markets: Evidence from China," Economic Development and Cultural Change, 59(3), 485-510.

[23] Kung, James Kai-sing. (2002): "Off-farm Labor Markets and the Emergence of Land Rental Markets in Rural China," Journal of Comparative Economics, 30(2), 395-414.

[24] Kung, James Kai-sing and Ying Bai. (2011): "Induced Institutional Change or Transaction Costs? The Economic Logic of Land Reallocations in Chinese Agriculture," Journal of Development Studies, 47(10): 1510-1528.

[25] Li, Lixing. (2011). "The Incentive Role of Creating 'Cities' in China." China Economic Review, $22(1): 172-181$.

[26] Lin, Justin Yifu. (1995): "Endowments, Technology, and Factor Markets: A Natural Experiment of Induced Institutional Innovation from China's Rural Reform," American Journal of Agricultural Economics, 77, 231-242.

[27] Lin, Justin Yifu. (1988): "Rural Factor Markets in China: After the Household Responsibility System Reform," in Chinese Economic Policy: Economic Reform at Midstream, ed. by Bruce Reynolds: New York, 169-203. 
[28] Liu, Shouying, Michael R. Carter, and Yang Yao. (1998): "Dimensions and Diversity of Property Rights in Rural China: Dilemmas on the Road to Further Reform," World Development, 26(10): 1789-1806.

[29] Lohmar, Bryan, Zhaoxin Zhang, and Agapi Somwaru. (2001): "Land Rental Market Development and Agricultural Production in China," Paper presented at the Annual Meetings of the American Agricultural Economics Association, Chicago: Illinois.

[30] Macours, Karen, Alain de Janvry, and Elisabeth Sadoulet. (2010): "Insecurity of Property Rights and Social Matching in the Tenancy Market," European Economic Review, 54: 880899.

[31] Newey, Whitney K. (1987): "Efficient Estimation of Limited Dependent Variable Models with Endogenous Explanatory Variables," Journal of Econometrics, 36(3): 231-250.

[32] Noev, Nivelin. (2008): "Contracts and Rental Behavior in the Bulgarian Land Market," Eastern European Economics, 46(4), 43-74.

[33] Otsuka, Keijiro, Hiroyuki Chuma, and Yujiro Hayami (1992): "Land and Labor Contracts in Agrarian Economies: Theories and Facts," Journal of Economic Literature, 30(4): 1965-2018.

[34] Rozelle, Scott and Guo Li. (1998): "Village Leaders and Land Rights Formation in China," American Economic Review, Papers and Proceedings, 88(2): 433-438.

[35] Rosenzweig, Mark R. and Kenneth I. Wolpin. (1993): "Credit Market Constraints, Consumption Smoothing, and the Accumulation of Durable Production Assets in Low-Income Countries: Investment in Bullocks in India," Journal of Political Economy, 101(2): 223-244.

[36] Tobin, James. (1958): "Estimation of Relationships for Limited Dependent Variables", Econometrica, 26(1): 24-36.

[37] Vranken, Liesbet and Johan Swinnen. (2006): "Land Rental Markets in Transition: Theory and Evidence from Hungary", World Development, 34(3), 481-500.

[38] Wooldridge, Jeffrey M. (2006): Introductory Econometrics: A Modern Approach. Beijing: Tsinghua University, 557-559.

[39] Xu, Chenggang. (2011). "The Fundamental Institutions of China's Reforms and Development." Journal of Economic Literature, 49(4): 1076-1151.

[40] Yang, Dennis Tao. (1997): "China's land Arrangement and Rural Labor Mobility," China Economic Review, 8(2), 101-115.

[41] Yao, Yang. (2000): "The Development of the Land Lease Market in Rural China," Land Economics, 76, 252-266. 
[42] Yao, Yang. (2004): "Land Tenure Choice in Chinese Villages: The Rational Versus the Political Model," Land Economics, 80, 477-489.

[43] Zhang, Junsen, Pak-Wai Liu, and Linda Yung. (2007): "The Cultural Revolution and Returns to Schooling in China: Estimates Based on Twins," Journal of Development Economics, 84: 631-639.

[44] Zhang, Qian Forrest, Qingguo Ma, and Xu Xu. (2004): "Development of Land Rental Markets in Rural Zhejiang: Growth of off-farm jobs and Institutional Building," China Quarterly, 180, 1050-1072. 
Table 1: Summary Statistics

\begin{tabular}{|l|l|l|l|l|l|}
\hline & Obs. & Mean & Std. Dev. & Min & Max \\
\hline Dependent Variables & & & & & \\
\hline Rent In & 2102 & 0.15 & 0.36 & 0 & 1 \\
\hline Rent Out & 2102 & 0.10 & 0.30 & 0 & 1 \\
\hline Rent In Size & 2102 & 1.43 & 8.42 & 0 & 200 \\
\hline Rent Out Size & 2102 & 0.23 & 1.04 & 0 & 21 \\
\hline Variables of Interest & & & & & \\
\hline FLR & 2102 & 1.44 & 1.69 & 0 & 8 \\
\hline PLR & 2102 & 0.68 & 1.47 & 0 & 20 \\
\hline Household Level Controls & & & & & \\
\hline Per Capita Arable Land & 2102 & 1.77 & 2.65 & 0 & 40.67 \\
\hline HH Head Age & 2100 & 46.75 & 11.24 & 20 & 86 \\
\hline HH Head Age Square & 2100 & 2312.09 & 1111.25 & 400 & 7396 \\
\hline Cadre Household & 2102 & 0.18 & 0.39 & 0 & 1 \\
\hline HH Head Education & 2102 & 2.62 & 0.87 & 0 & 8 \\
\hline Population <16 & 2102 & 0.73 & 0.74 & 0 & 4 \\
\hline Population 16-60 & 2102 & 2.90 & 1.23 & 0 & 8 \\
\hline Population >60 & 2102 & 0.38 & 0.66 & 0 & 3 \\
\hline Female Ratio & 2102 & 0.49 & 0.16 & 0 & 1 \\
\hline Share of Off Farm Workers & 2102 & 0.25 & 0.24 & 0 & 1 \\
\hline Agricultural Tax & 2102 & 4.60 & 1.53 & 0 & 7.40 \\
\hline Non-farm Assets & 2102 & 0.84 & 2.81 & 0 & 14.69 \\
\hline Hogs & 2102 & 0.91 & 1.20 & 0.01 & 7.86 \\
\hline Cattles & 2102 & 0.05 & 0.20 & 0.01 & 2.30 \\
\hline Village Level Controls & & & & & \\
\hline Distance to County & 2077 & 22.82 & 15.85 & 0.2 & 70 \\
\hline Sanction & 2102 & 0.10 & 0.30 & 0 & 1 \\
\hline Rent & 2102 & 0.08 & 0.26 & 0 & 2.5 \\
\hline
\end{tabular}


Table 2: Procedures of FLR among Villages Conducting FLR (\%)

\begin{tabular}{ll}
\hline \hline Villagers' session & 85.5 \\
Selecting villagers' deputy & 72.7 \\
Estimating size of land & 72.7 \\
Lottery for land & 74.6 \\
Issuing new land contract & 70.9 \\
\hline
\end{tabular}

Table 3: Willingness of Land Holding

\begin{tabular}{|c|c|c|c|c|c|}
\hline & & \multicolumn{2}{|c|}{ Increase or Decrease $(\%)$} & No Change (\%) & \\
\hline No FLR and $\mathrm{F}$ & $\operatorname{LR}(5.1 \%)$ & \multicolumn{2}{|c|}{50.51} & 49.49 & \\
\hline Only PLR (34 & $3 \%)$ & \multicolumn{2}{|l|}{47.46} & 52.54 & \\
\hline Both FLR and & PLR $(32.3 \%)$ & \multicolumn{2}{|l|}{51.13} & 48.87 & \\
\hline Only FLR (28 & $2 \%)$ & \multicolumn{2}{|l|}{60.45} & 39.55 & \\
\hline \multicolumn{6}{|c|}{$\begin{array}{l}\text { Notes: Data source is DRC } 2003 \text { Survey. We divided the sample into } 4 \text { groups: villages conducting } \\
\text { no FLR and PLR, villages conducting only PLR, villages conducting both FLR and PLR and } \\
\text { villages conducting only FLR. Percentage of households in each group is in the parenthesis. }\end{array}$} \\
\hline \multicolumn{6}{|c|}{ Table 4: Household Land Rental Activity } \\
\hline Province & Rent in $(\%)$ & Rent out (\%) & Area in (mu) & Area out $(\mathrm{mu})$ & "Land reallocation Frequency \\
\hline Hunan & 13.2 & 11.2 & 0.27 & 0.19 & 2.75 \\
\hline Zhejiang & 18.6 & 22.3 & 2.40 & 0.28 & 1.74 \\
\hline Fujian & 22.8 & 12.8 & 1.63 & 0.54 & 3.97 \\
\hline Sichuan & 14.8 & 8.8 & 0.21 & 0.15 & 1.18 \\
\hline Anhui & 8.8 & 4.6 & 0.38 & 0.11 & 1.68 \\
\hline Heilongjiang & 11.7 & 0.9 & 3.69 & 0.11 & 0.89 \\
\hline Average & 15.0 & 10.1 & 1.43 & 0.23 & 2.0 \\
\hline
\end{tabular}


Table 5: Results for Household Renting In Land






\begin{tabular}{|c|c|c|c|c|c|c|}
\hline Agricultural Tax & & $\begin{array}{l}-0.036 \\
(0.027)\end{array}$ & $\begin{array}{l}0.034 \\
(0.031)\end{array}$ & & $\begin{array}{l}-1.381 * * \\
(0.649)\end{array}$ & $\begin{array}{l}0.553 \\
(0.735)\end{array}$ \\
\hline Non-agricultural Assets & & $\begin{array}{c}-0.028 * \\
(0.016)\end{array}$ & $\begin{array}{l}-0.044 * * * \\
(0.016)\end{array}$ & & $\begin{array}{l}-0.282 \\
(0.518)\end{array}$ & $\begin{array}{c}-0.663 \\
(0.448)\end{array}$ \\
\hline Number of Hogs & & $\begin{array}{l}0.165 * * * \\
(0.028)\end{array}$ & $\begin{array}{l}0.159 * * * \\
(0.029)\end{array}$ & & $\begin{array}{l}2.964 * * * \\
(0.697)\end{array}$ & $\begin{array}{l}2.624 * * * \\
(0.684)\end{array}$ \\
\hline Number of Cattles & & $\begin{array}{l}0.132 \\
(0.169)\end{array}$ & $\begin{array}{l}0.185 \\
(0.177)\end{array}$ & & $\begin{array}{l}-0.418 \\
(3.682)\end{array}$ & $\begin{array}{l}0.718 \\
(3.639)\end{array}$ \\
\hline Renting Allowed & & $\begin{array}{l}0.058 \\
(0.116)\end{array}$ & $\begin{array}{l}0.026 \\
(0.129)\end{array}$ & & $\begin{array}{l}4.470 \\
(3.072)\end{array}$ & $\begin{array}{l}4.694 \\
(3.119)\end{array}$ \\
\hline Average Rent & & $\begin{array}{l}0.190 \\
(0.124)\end{array}$ & $\begin{array}{l}-0.004 \\
(0.134)\end{array}$ & & $\begin{array}{l}3.766 \\
(2.549)\end{array}$ & $\begin{array}{l}-1.276 \\
(2.729)\end{array}$ \\
\hline Log Pseudo Likelihood & -873 & -816 & -779 & -1981 & -1890 & -1849 \\
\hline Observations & 2102 & 2075 & 2075 & 2102 & 2075 & 2075 \\
\hline
\end{tabular}

Notes: White's robust standard errors are in parentheses. DV represents dependent variable.

* significant at $10 \%$; ** significant at $5 \%$; *** significant at $1 \%$ 
Table 6: Results for Household Renting Out Land

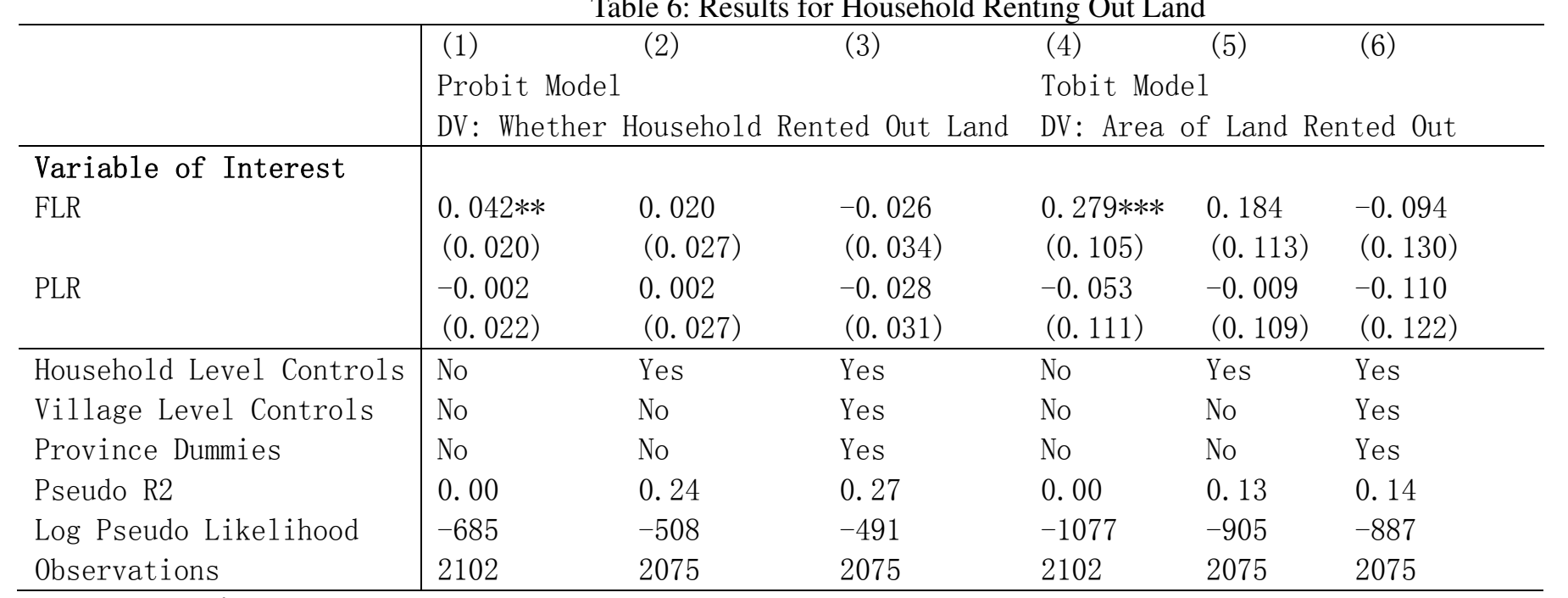

Notes: White's standard errors clustered at province level are in parentheses. DV represents dependent variable. * significant at $10 \% ; * *$ significant at $5 \%$; *** significant at $1 \%$ 
Table 7: Alternative Dummy Dependent Variable Models

\begin{tabular}{l|llllll}
\hline & $(1)$ & $(2)$ & $(3)$ & $(4)$ & $(5)$ & $(6)$ \\
& LPM & Logit & Semi-parametric & LPM & Logit & Semi-parametric \\
& DV: Whether Household Rented In Land & DV: Whether Household Rented Out Land \\
\hline Variable of Interest & & & & & & \\
FLR & $0.024 * * *$ & $0.184 * * *$ & $0.217 * *$ & -0.002 & -0.058 & -0.025 \\
& $(0.007)$ & $(0.056)$ & $(0.091)$ & $(0.006)$ & $(0.063)$ & $(0.024)$ \\
PLR & $-0.013 * * *$ & $-0.148 * *$ & $-0.090 *$ & -0.005 & -0.064 & -0.041 \\
& $(0.004)$ & $(0.061)$ & $(0.048)$ & $(0.003)$ & $(0.063)$ & $(0.033)$ \\
\hline Household Level Controls & Yes & Yes & Yes & Yes & Yes & Yes \\
Village Level Controls & Yes & Yes & Yes & Yes & Yes & Yes \\
Province Dummies & Yes & Yes & Yes & Yes & Yes & Yes \\
R2/Pseudo R2 & 0.10 & 0.11 & & 0.20 & 0.27 & -476 \\
Log Pseudo Likelihood & & -777 & -767 & & -488 & 2075 \\
Observations & 2075 & 2075 & 2075 & 2075 & 2075 \\
\hline
\end{tabular}

Notes: white's standard errors clustered at province level are in parentheses. DV represents dependent variable. * significant at $10 \% ; * *$ significant at $5 \%$; *** significant at $1 \%$ 
Table 8: Subsamples for Robustness

\begin{tabular}{|c|c|c|c|c|c|c|c|c|}
\hline & $\begin{array}{l}\text { Excluding } \\
\text { Probit } \\
\text { Rented In }\end{array}$ & $\begin{array}{l}\text { Heilongjiang Prc } \\
\text { Tobit } \\
\text { Size Rented In }\end{array}$ & $\begin{array}{l}\text { Vince } \\
\text { Probit } \\
\text { Rented Out }\end{array}$ & $\begin{array}{l}\text { Tobit } \\
\text { Size Rented out }\end{array}$ & $\begin{array}{l}\text { Excluding } \\
\text { Probit } \\
\text { Rented In }\end{array}$ & $\begin{array}{l}\text { Zhejiang Provinc } \\
\text { Tobit } \\
\text { Size Rented In }\end{array}$ & $\begin{array}{l}\text { e } \\
\text { Probit } \\
\text { Rented out }\end{array}$ & $\begin{array}{l}\text { Tobit } \\
\text { Size Rented Out }\end{array}$ \\
\hline FLR & $\begin{array}{l}0.097 * * * \\
(0.032)\end{array}$ & $\begin{array}{l}1.417 * * \\
(0.618)\end{array}$ & $\begin{array}{l}-0.020 \\
(0.034)\end{array}$ & $\begin{array}{l}-0.067 \\
(0.106)\end{array}$ & $\begin{array}{l}0.078 * * \\
(0.035)\end{array}$ & $\begin{array}{l}1.451 * * * \\
(0.533)\end{array}$ & $\begin{array}{l}-0.042 \\
(0.039)\end{array}$ & $\begin{array}{l}-0.181 \\
(0.187)\end{array}$ \\
\hline PLR & $\begin{array}{l}-0.077 * * \\
(0.032)\end{array}$ & $\begin{array}{c}-1.016 * \\
(0.539)\end{array}$ & $\begin{array}{l}-0.026 \\
(0.031)\end{array}$ & $\begin{array}{l}-0.083 \\
(0.097)\end{array}$ & $\begin{array}{c}-0.067 * \\
(0.035)\end{array}$ & $\begin{array}{c}-1.020 * \\
(0.589)\end{array}$ & $\begin{array}{l}-0.017 \\
(0.034)\end{array}$ & $\begin{array}{l}-0.113 \\
(0.171)\end{array}$ \\
\hline Household Controls & Yes & Yes & Yes & Yes & Yes & Yes & Yes & Yes \\
\hline Village Controls & Yes & Yes & Yes & Yes & Yes & Yes & Yes & Yes \\
\hline Province Dummies & Yes & Yes & Yes & Yes & Yes & Yes & Yes & Yes \\
\hline Pseudo R2 & 0.12 & 0.05 & 0.24 & 0.14 & 0.11 & 0.08 & 0.26 & 0.15 \\
\hline Log Pseudo Likelihood & -663 & -1543 & -472 & -821 & -630 & -1408 & -339 & -601 \\
\hline Observations & 1727 & 1727 & 1727 & 1727 & 1726 & 1726 & 1726 & 1726 \\
\hline
\end{tabular}

Notes: white's standard errors clustered at province level are in parentheses.

$*$ significant at $10 \%$; ** significant at $5 \%$; *** significant at $1 \%$ 
Table 9: Alternative Measures of FLR and PLR: Latest Land Reallocation is FLR or PLR

\begin{tabular}{|c|c|c|c|c|c|c|c|c|}
\hline & $\begin{array}{l}\text { (1) } \\
\text { Probit } \\
\text { Rented In }\end{array}$ & (2) & $\begin{array}{l}(3) \\
\text { Tobit } \\
\text { Size Rente }\end{array}$ & $\begin{array}{l}\text { (4) } \\
\text { ed } \mathrm{In}\end{array}$ & $\begin{array}{l}(5) \\
\text { Probit } \\
\text { Rented }\end{array}$ & (6) & $\begin{array}{l}(7) \\
\text { Tobit } \\
\text { Size Rer }\end{array}$ & $\begin{array}{l}\text { (8) } \\
\text { ted Out }\end{array}$ \\
\hline Latest Land Reallocation is FLR & $\begin{array}{l}0.367 * * * \\
(0.096)\end{array}$ & & $\begin{array}{l}\text { 7. 582*** } \\
(2.201)\end{array}$ & & $\begin{array}{c}0.218 * * \\
(0.110)\end{array}$ & & $\begin{array}{c}0.880 * * \\
(0.416)\end{array}$ & \\
\hline Latest Land Reallocation is PLR & & $\begin{array}{c}-0.206 * * \\
(0.091)\end{array}$ & & $\begin{array}{c}-2.839 \\
(2.158) \\
\end{array}$ & & $\begin{array}{c}-0.042 \\
(0.106) \\
\end{array}$ & & $\begin{array}{c}-0.262 \\
(0.393) \\
\end{array}$ \\
\hline Village Controls & Yes & Yes & Yes & Yes & Yes & Yes & Yes & Yes \\
\hline Province Dummies & Yes & Yes & Yes & Yes & Yes & Yes & Yes & Yes \\
\hline Observations & 2075 & 2075 & 2075 & 2075 & 2075 & 2075 & 2075 & 2075 \\
\hline
\end{tabular}

Notes: white's standard errors clustered at province level are in parentheses

* significant at $10 \%$; ** significant at $5 \%$; *** significant at $1 \%$ 
Table 10: Alternative Measures of FLR and PLR: Only Experienced FLR or PLR

\begin{tabular}{|c|c|c|c|c|c|c|c|c|}
\hline & $\begin{array}{l}\text { (1) } \\
\text { Probit } \\
\text { Rented In }\end{array}$ & (2) & $\begin{array}{l}\text { (3) } \\
\text { Tobit } \\
\text { Size Rente }\end{array}$ & (4) $\mathrm{In}$ & $\begin{array}{l}(5) \\
\text { Probit } \\
\text { Rented }\end{array}$ & $\begin{array}{l}\text { (6) } \\
\text { ut }\end{array}$ & $\begin{array}{l}(7) \\
\text { Tobit } \\
\text { Size Rent }\end{array}$ & $\begin{array}{l}\text { (8) } \\
\text { ted Out }\end{array}$ \\
\hline Only Experienced FLR & $\begin{array}{l}0.288 * * * \\
(0.095)\end{array}$ & & $\begin{array}{l}5.813 * * * \\
(2.103)\end{array}$ & & $\begin{array}{c}0.217 * * \\
(0.106)\end{array}$ & & $\begin{array}{c}0.891 * * \\
(0.402)\end{array}$ & \\
\hline Only Experienced PLR & & $\begin{array}{c}-0.227 * * \\
(0.093)\end{array}$ & & $\begin{array}{c}-4.865 * * \\
(2.416) \\
\end{array}$ & & $\begin{array}{l}0.040 \\
(0.113)\end{array}$ & & $\begin{array}{l}0.021 \\
(0.419)\end{array}$ \\
\hline Household Controls & Yes & Yes & Yes & Yes & Yes & Yes & Yes & Yes \\
\hline Village Controls & Yes & Yes & Yes & Yes & Yes & Yes & Yes & Yes \\
\hline Province Dummies & Yes & Yes & Yes & Yes & Yes & Yes & Yes & Yes \\
\hline Pseudo R2 & 0.11 & 0.10 & 0.06 & 0.06 & 0.27 & 0.27 & 0.15 & 0.14 \\
\hline Log Pseudo Likelihood & -784 & -786 & -1852 & -1853 & -490 & -492 & -885 & -888 \\
\hline Observations & 2075 & 2075 & 2075 & 2075 & 2075 & 2075 & 2075 & 2075 \\
\hline
\end{tabular}

Notes: white's robust standard errors clustered at province level in parentheses

* significant at $10 \%$; ** significant at $5 \%$; *** significant at $1 \%$ 
Table 11: Are In-rentee Households More productive?

\begin{tabular}{l|lll}
\hline & $(1)$ & $(2)$ & $(3)$ \\
& Dependent & Variable is Value of & Farm Production \\
\hline Rent In Dummy & $1.537 * * *$ & $1.242 * * *$ & $1.186 * * *$ \\
Arable Land & $(0.284)$ & $(0.232)$ & $(0.247)$ \\
& & $1.728 * * *$ & $1.929 * * *$ \\
Labor & & $(0.151)$ & $(0.464)$ \\
& & 0.227 & 0.081 \\
Share of Off Farm Members & & $(0.164)$ & $(0.236)$ \\
& & $-0.550 * *$ & $-1.340 * * *$ \\
Land Quality & & $(0.166)$ & $(0.327)$ \\
Fertilizer & & 0.488 & 0.228 \\
& & $(0.246)$ & $(0.176)$ \\
Number of Hogs & 0.048 & 0.023 \\
& & $(0.111)$ & $(0.095)$ \\
Number of Cattles & & $0.190 * *$ & $0.328 * * *$ \\
& & $(0.066)$ & $(0.081)$ \\
\hline Province Dummies & & -0.105 & -0.052 \\
Observations & & $(0.317)$ & $(0.333)$ \\
R-squared & No & No & Yes \\
\hline
\end{tabular}

Notes: White's robust standard errors clustered at province level are in parentheses. * significant at $10 \%$; $* *$ significant at $5 \%$; $* * *$ significant at $1 \%$ 
Figure 1 Trend of Household Land Rental Market Participation

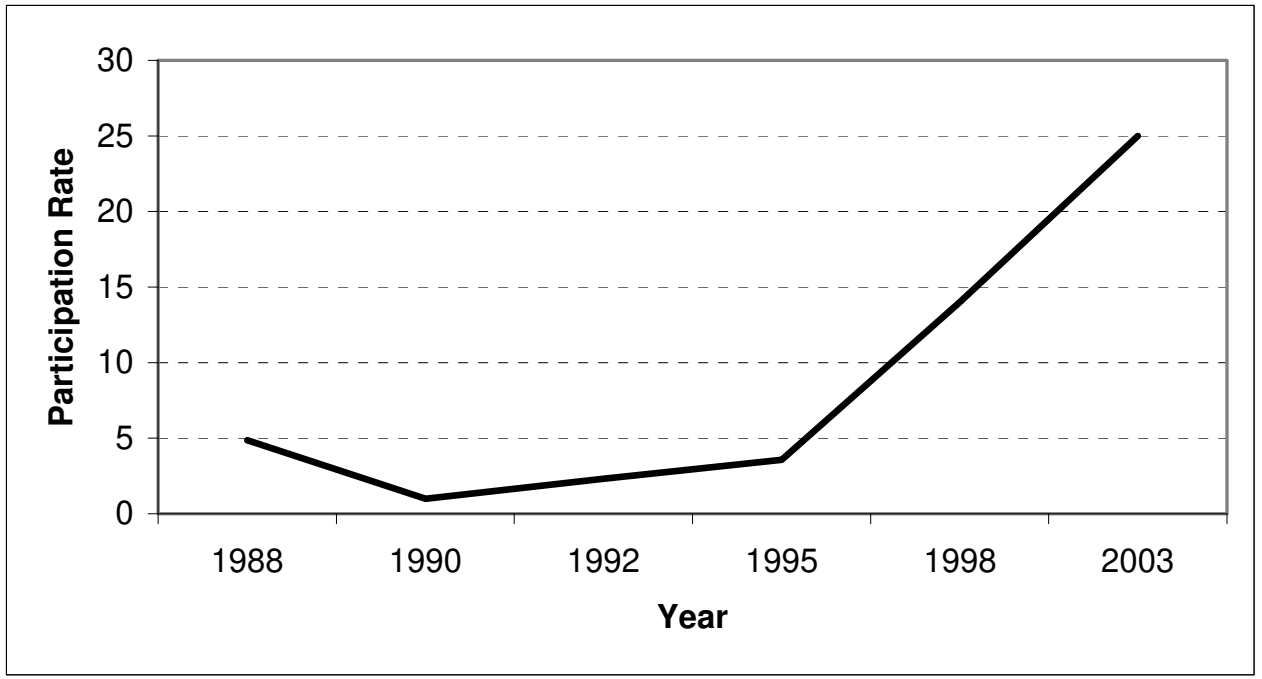

Source: Zhang, Ma and Xu (2004), Brandt, Huang, Li and Rozelle (2002) and Lohmar, Zhang and Somwaru (2001) 
Figure 2: Geographical Distribution of Surveyed Provinces

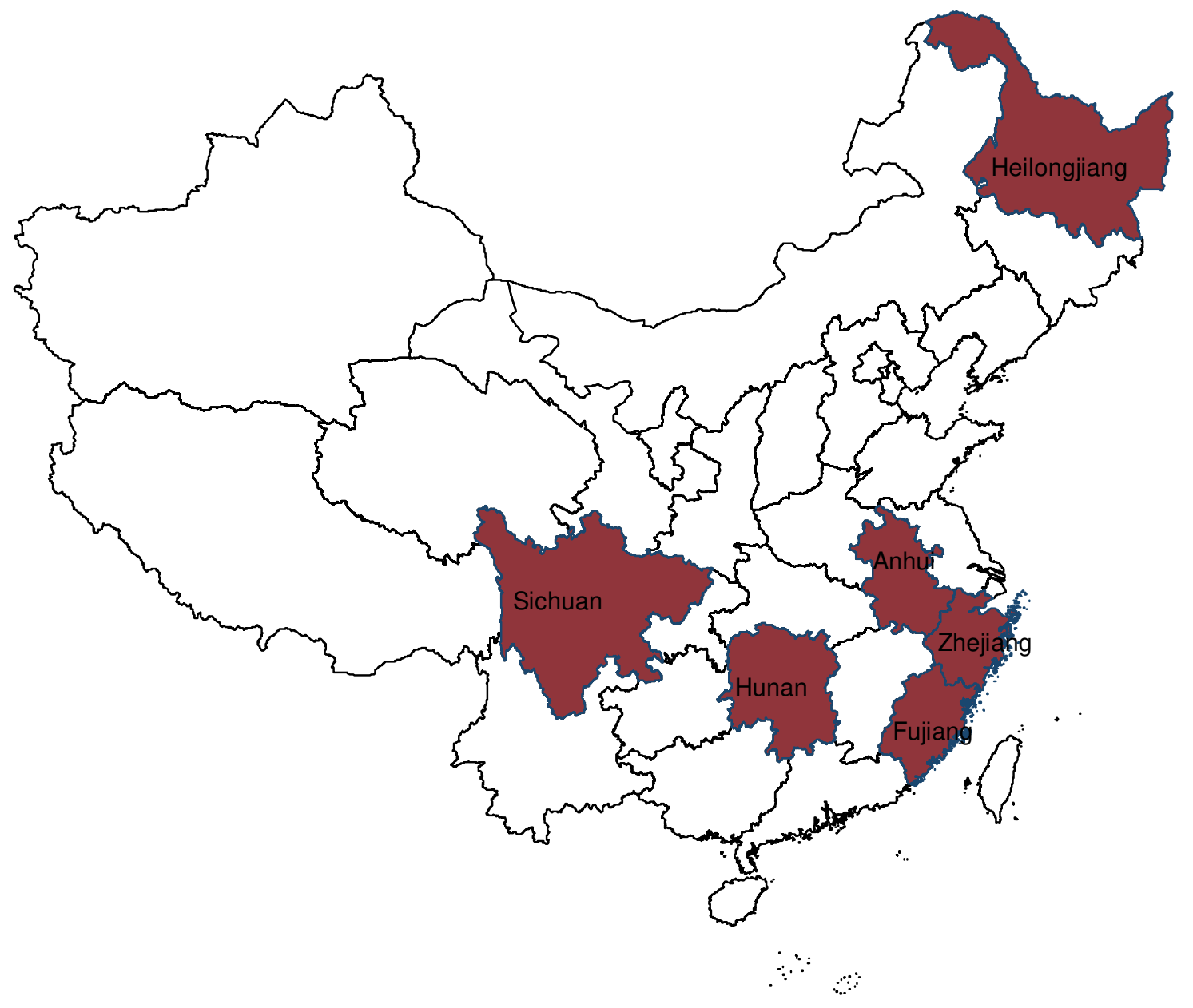


Figure 3A: Number of FLR and Percentage of Households Rented In Land

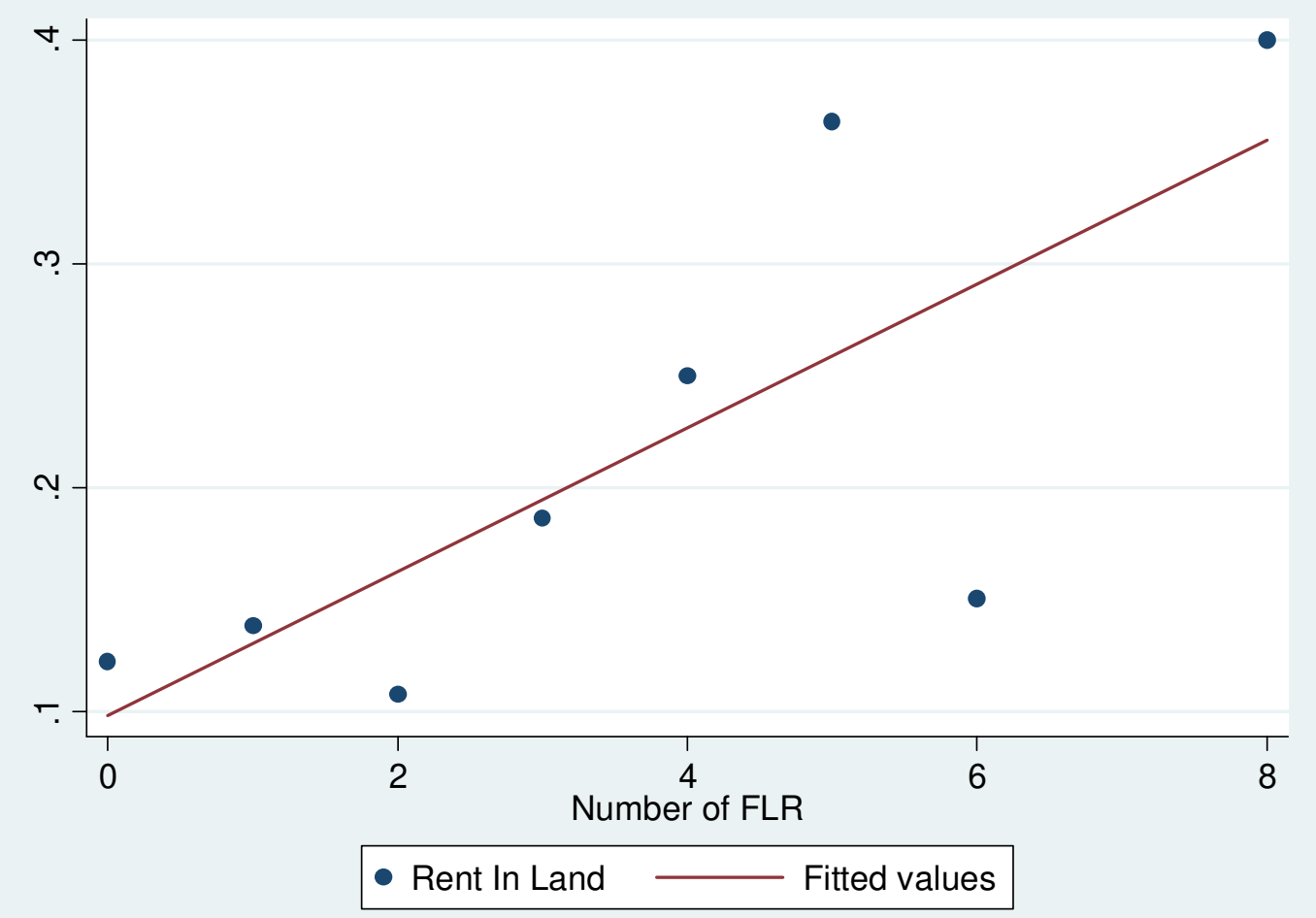

Figure 3B: Number of FLR and Percentage of Households Rented Out Land

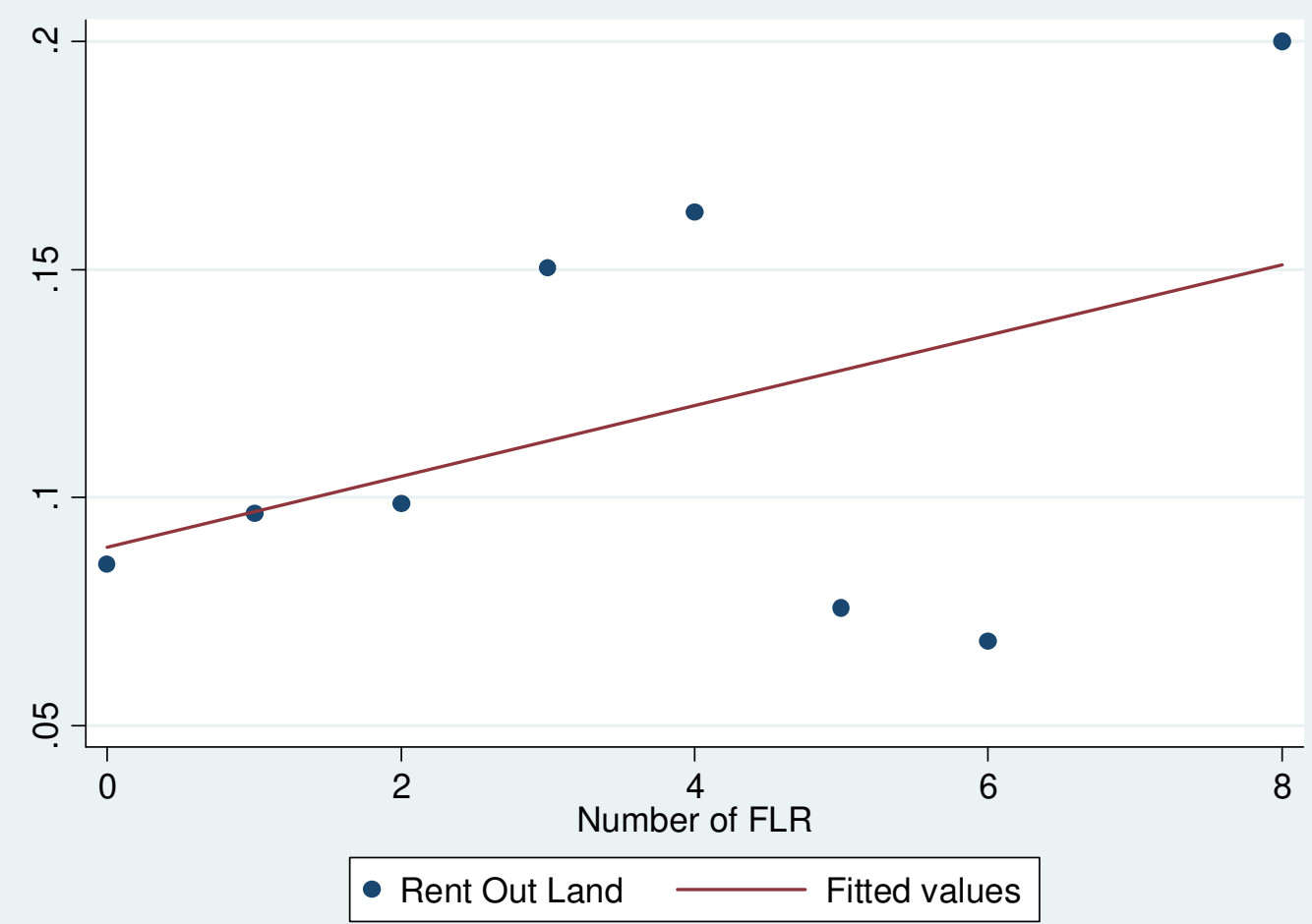


Figure 3C: Number of FLR and Average Size of Land Rented In

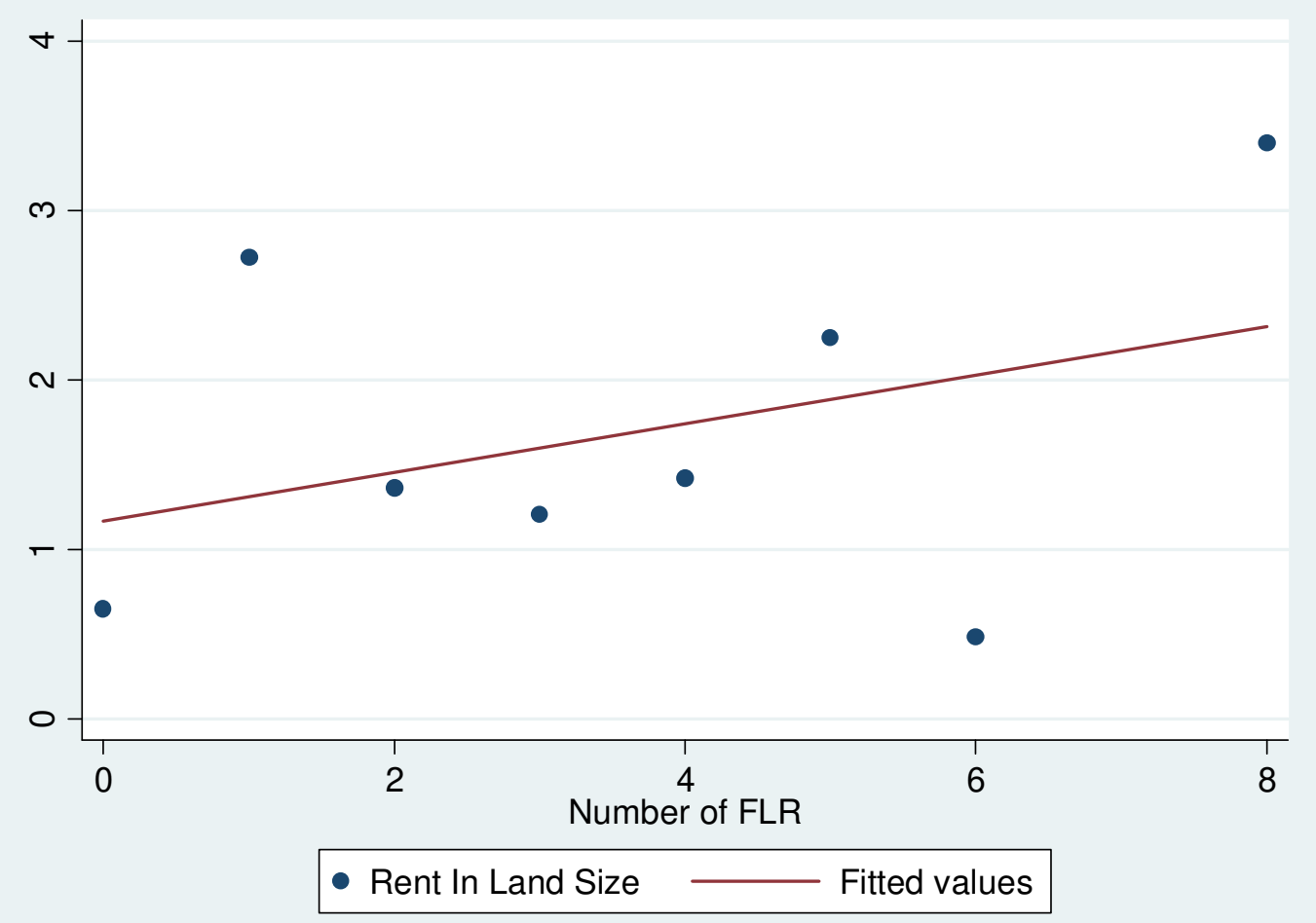

Figure 3D: Number of FLR and Average Size of Land Rented Out

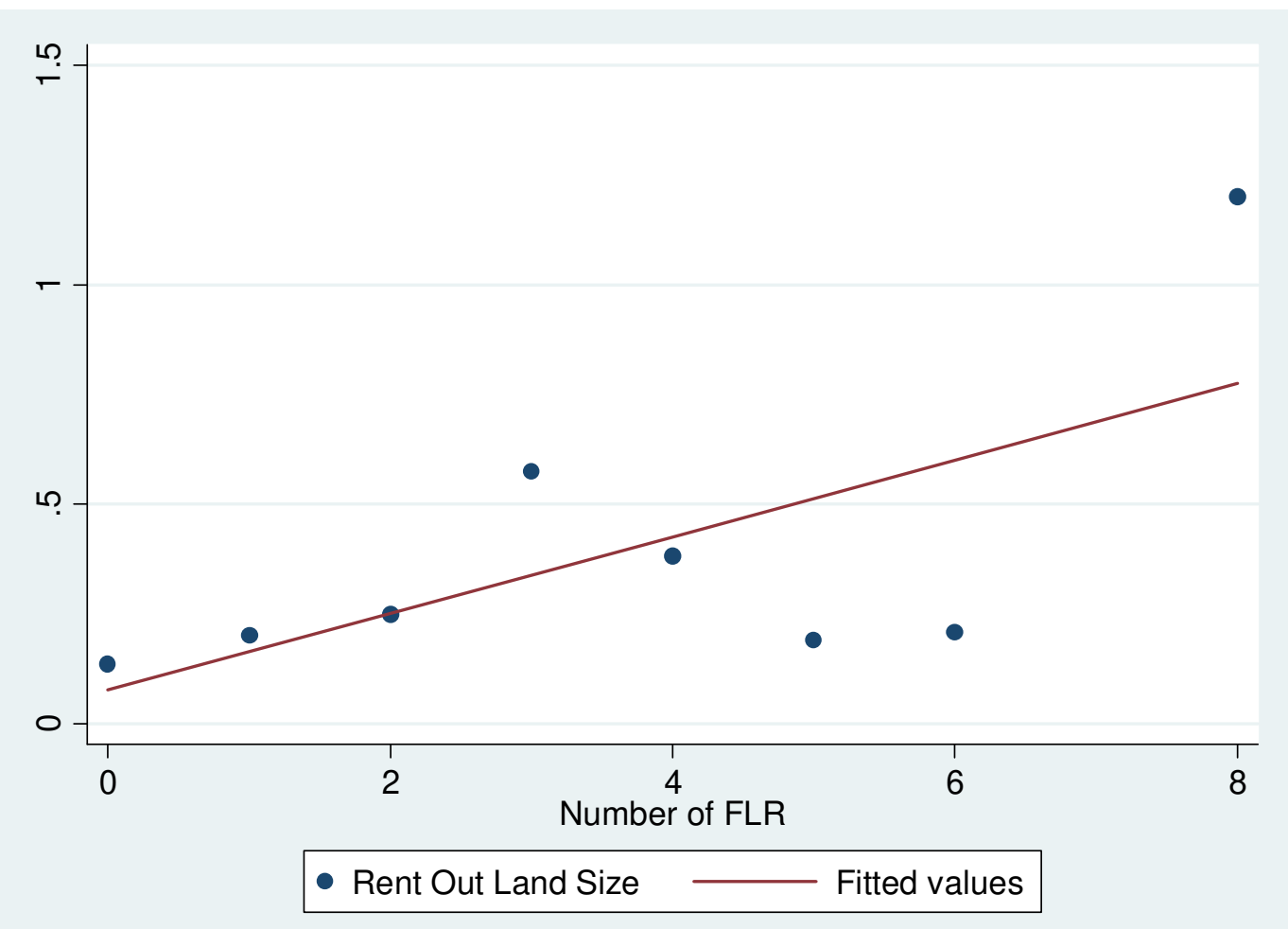


Figure 4A: Number of PLR and Percentage of Households Rented In Land

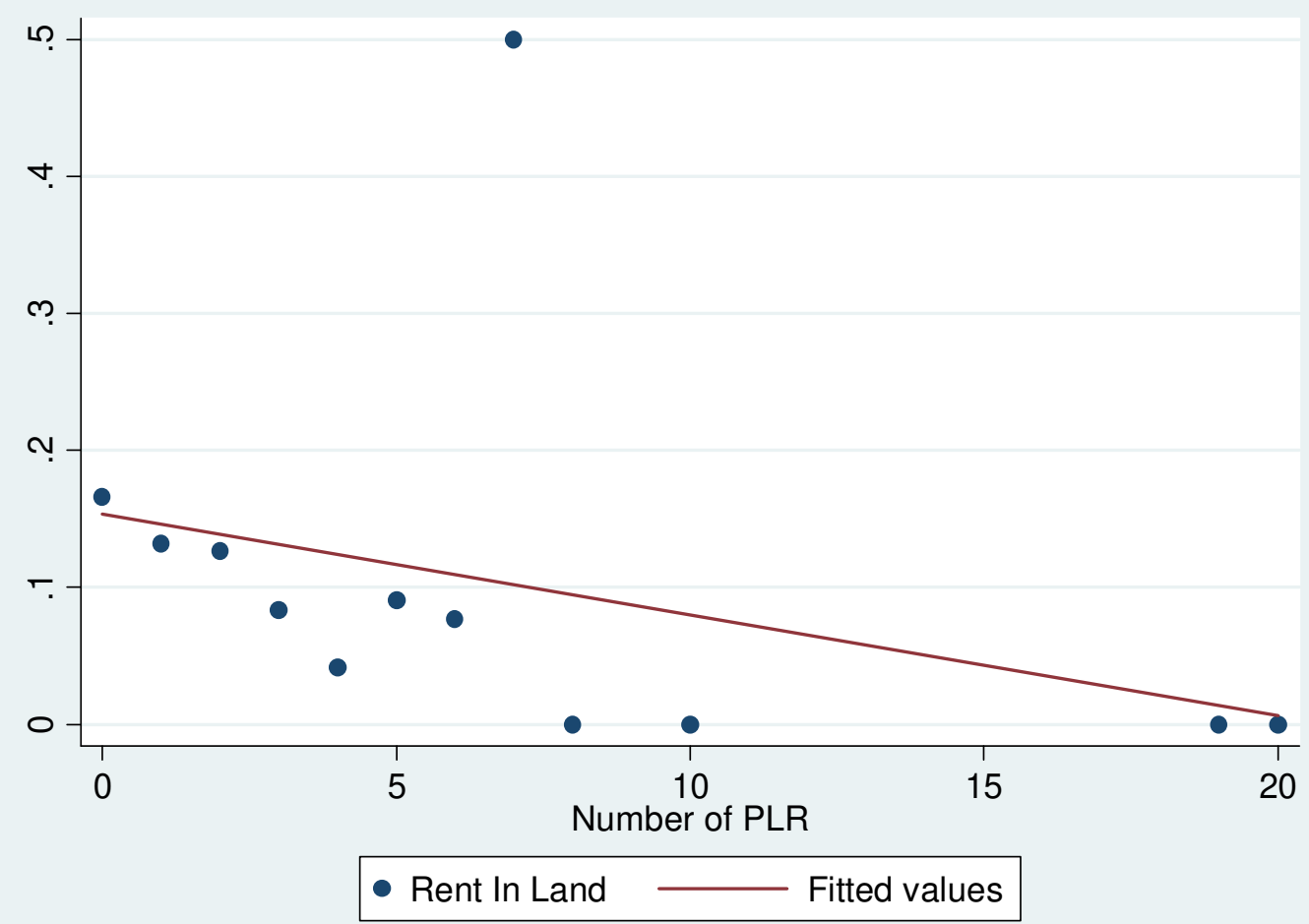

Figure 4B: Number of PLR and Percentage of Households Rented Out Land




Figure 4C: Number of PLR and Average Size of Land Rented In



Figure 4D: Number of PLR and Average Size of Land Rented Out



- Rent Out Land Size - Fitted values 
Figure 5A: Demand Recovery Land Rental after FLR When the Household is Initially in Autarky

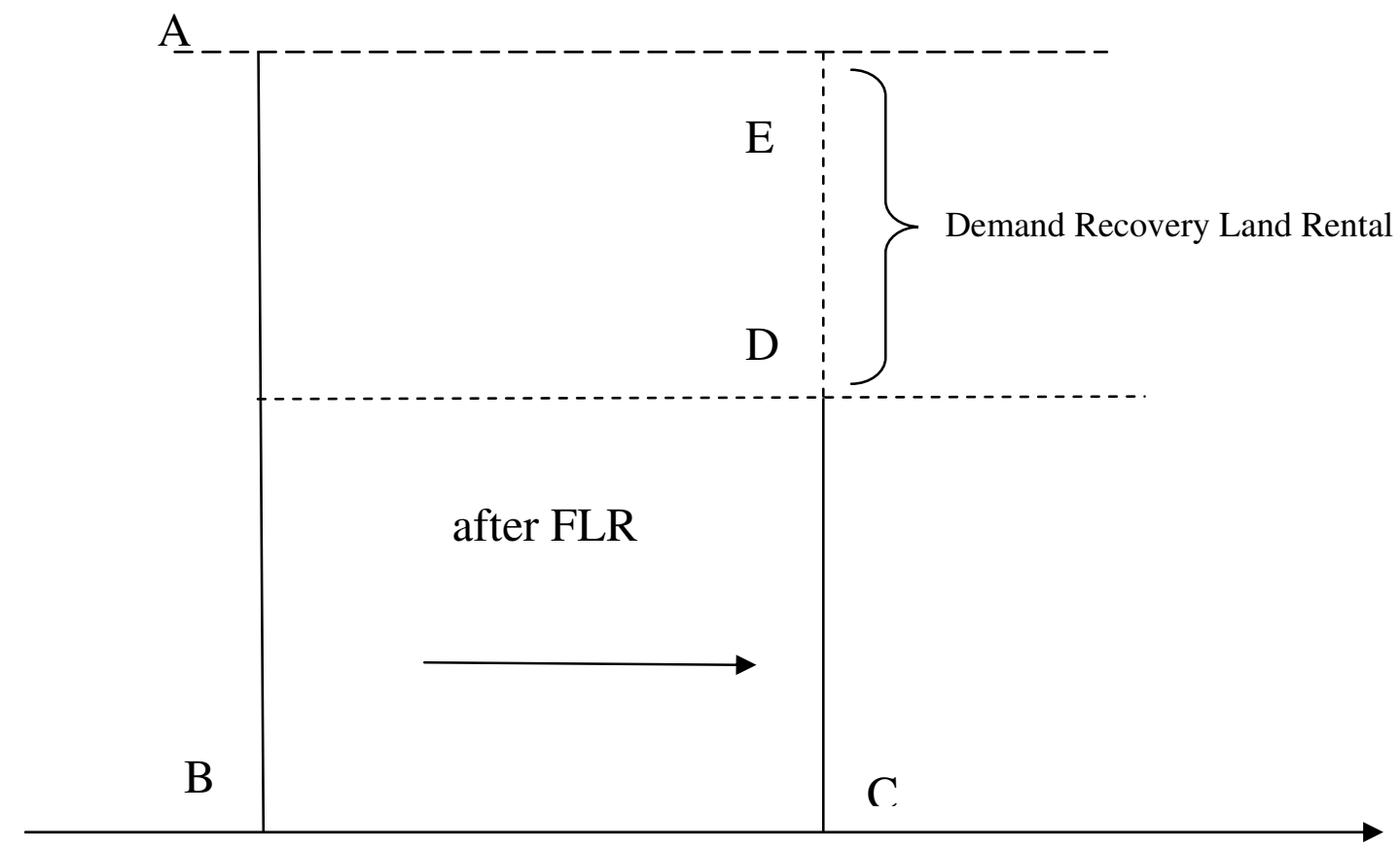


Figure 5B: Supply Recovery Land Rental after FLR When the Household is Initially in Autarky




Figure 6A: Demand Recovery Land Rental after FLR When Household Initially Rented in Land

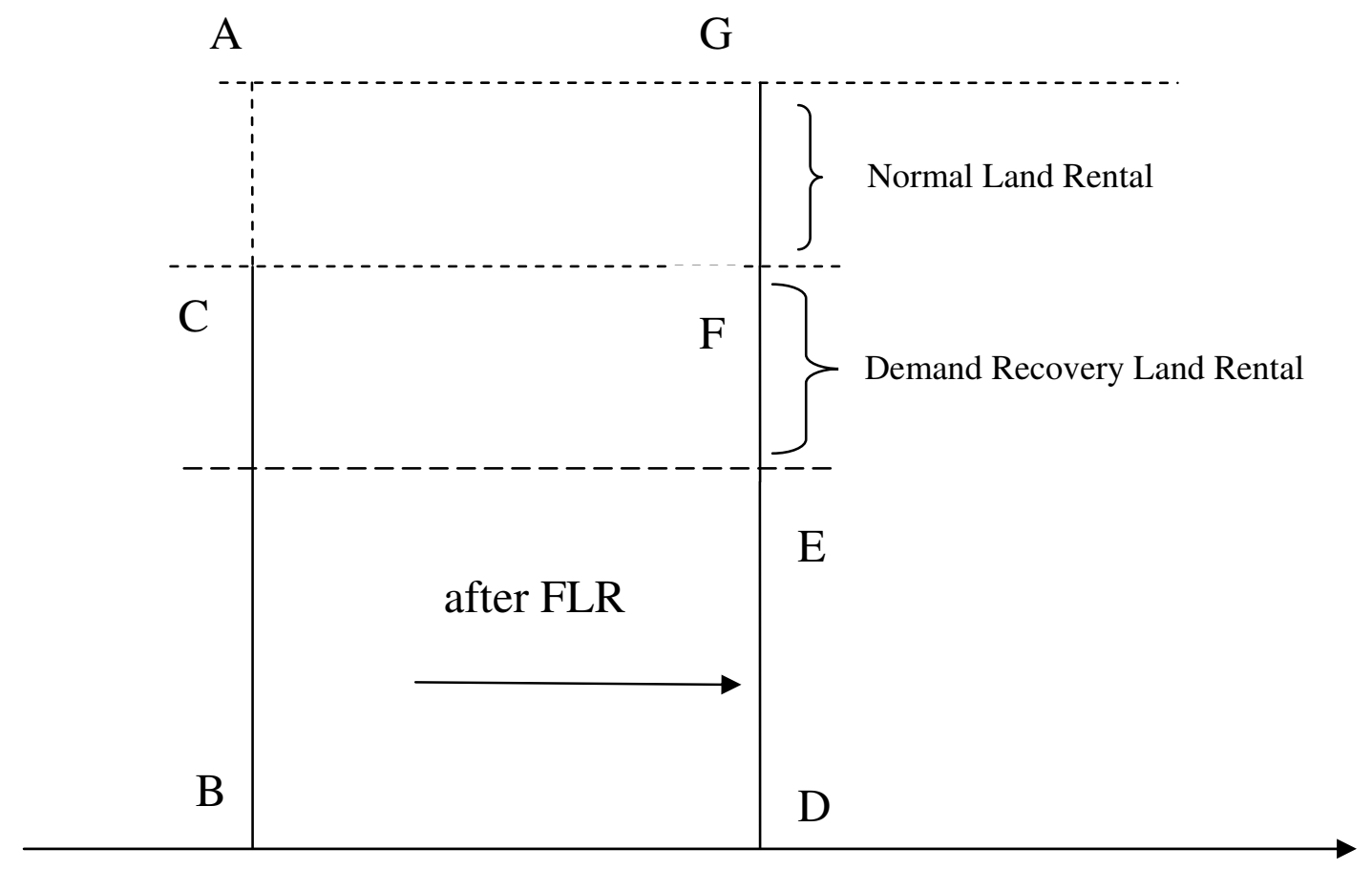


Figure 6B: No Land Rental after FLR When the Household Initially Rented in Land




Figure 6C: Supply Recovery Land Rental after FLR When the Household Initially Rented in Land




Figure 6D: Land Rental after FLR When the Household Initially Rented in Land

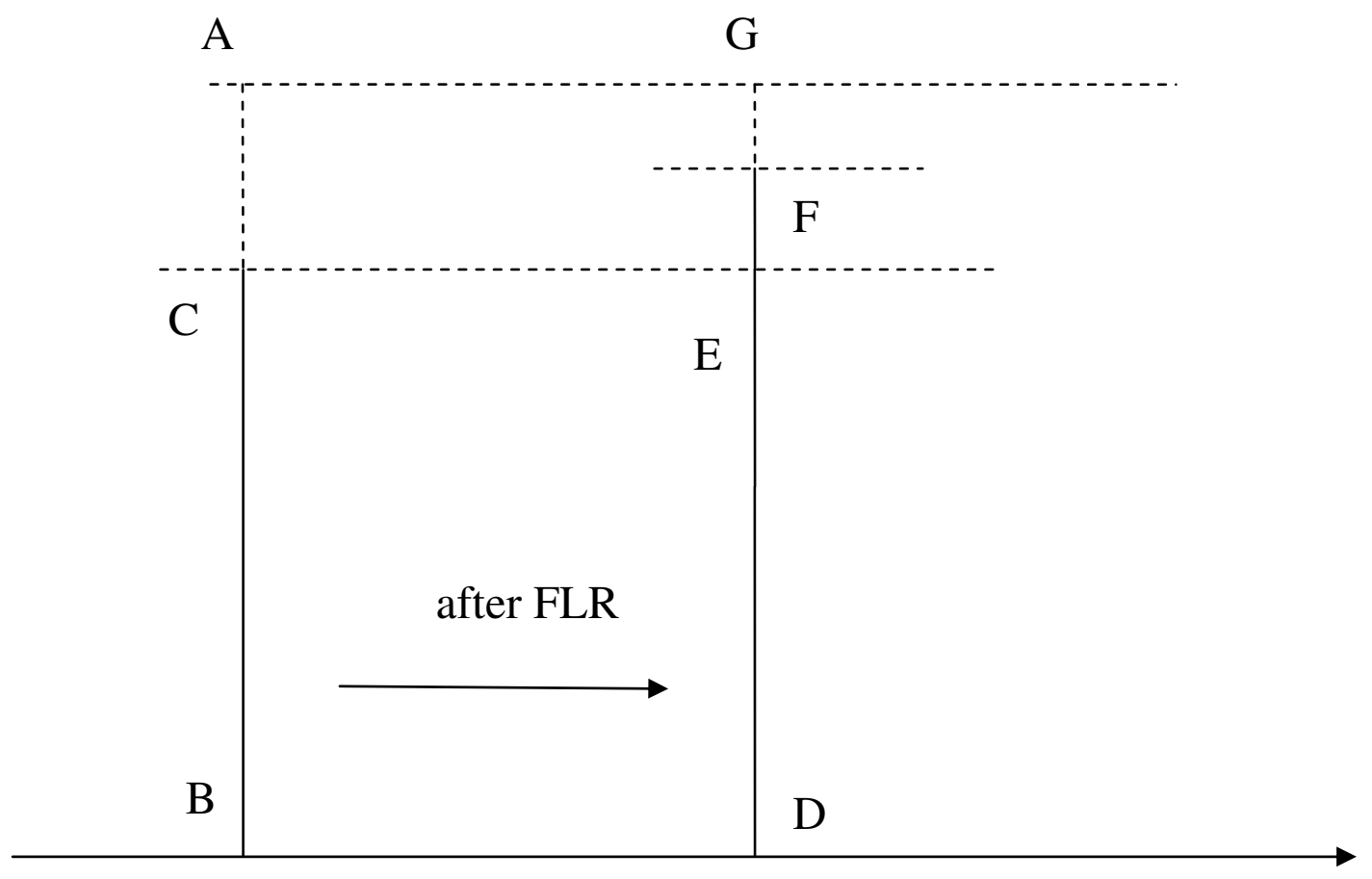


Figure 7A: Supply Recovery Land Rental after FLR When the Household Initially Rented in Land

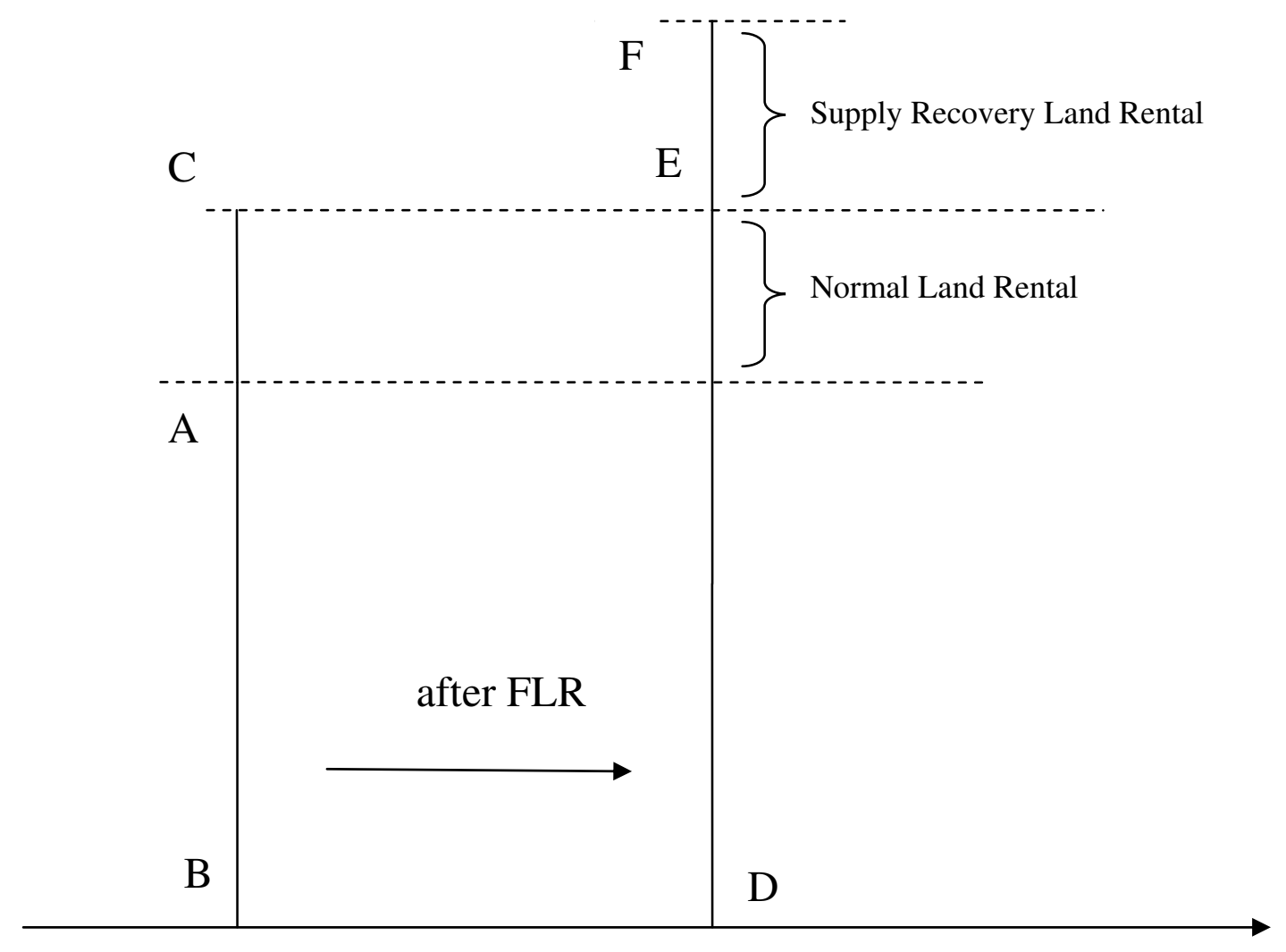


Figure 7B: No Land Rental after FLR When the Household Initially Rented in Land

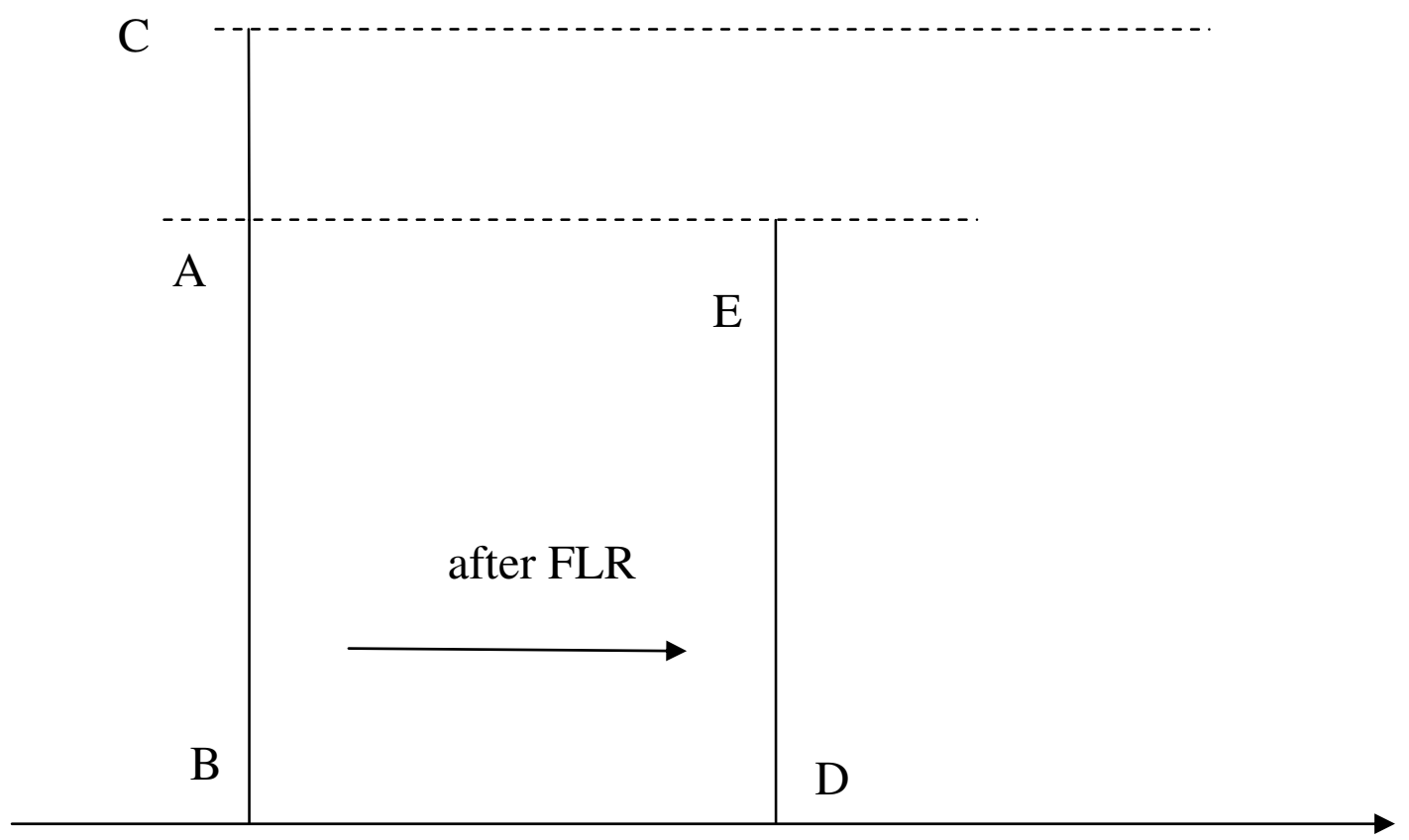


Figure 7C: Land Rental after FLR When the Household Initially Rented in Land

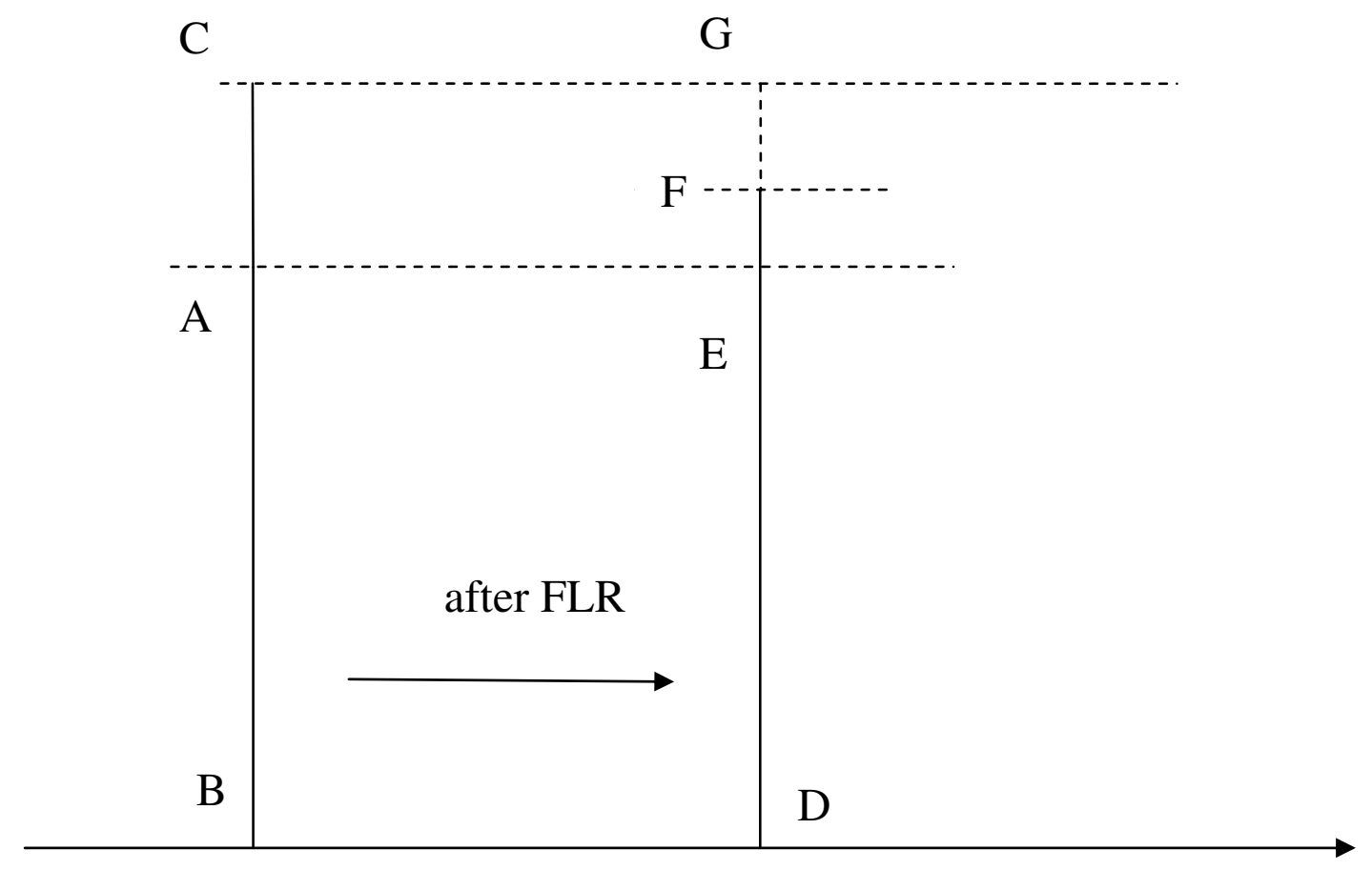


Figure 7D: Demand Recovery Land Rental after FLR When Household Initially Rented in Land

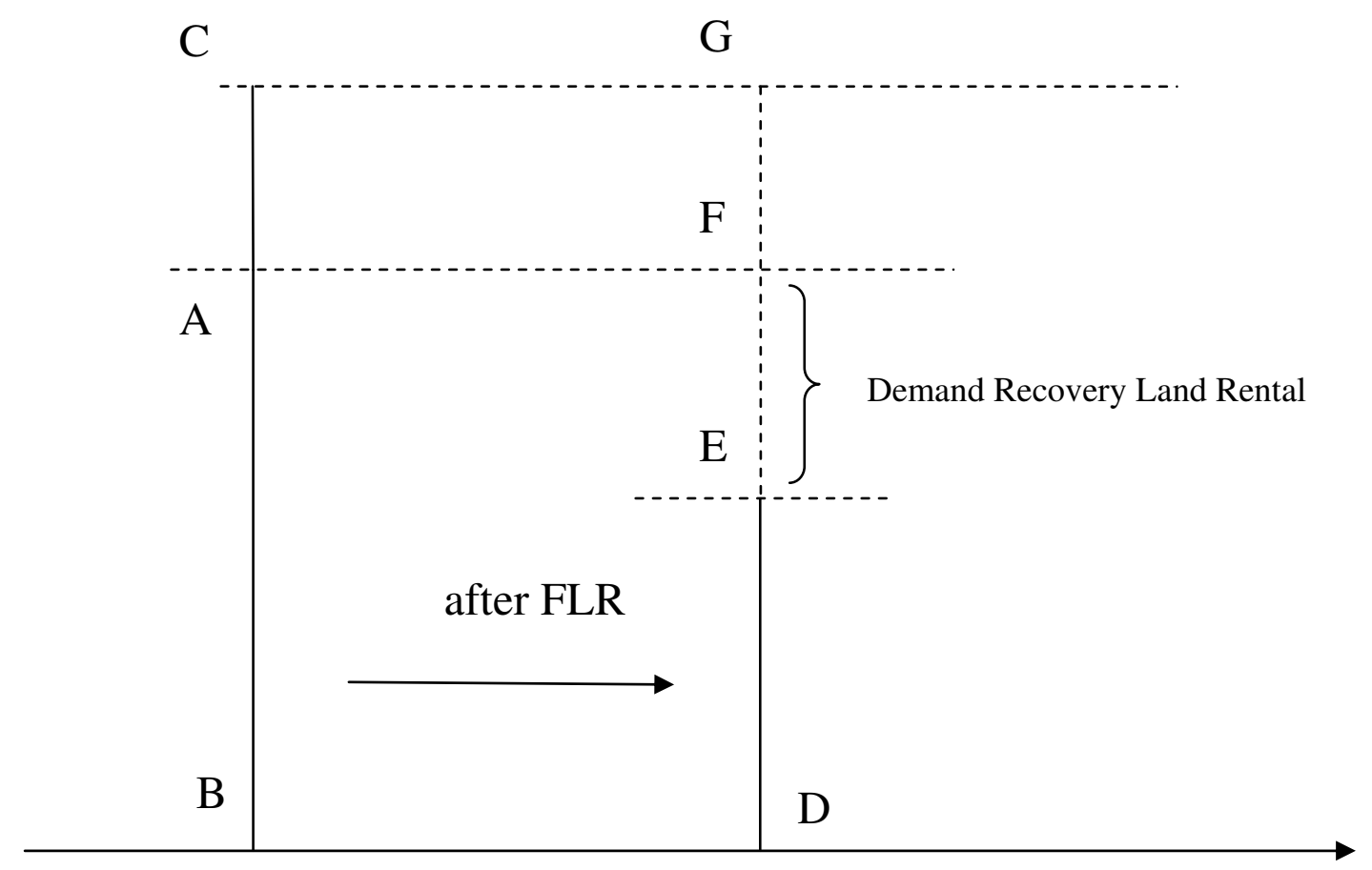


Figure 8: Land Rental after PLR

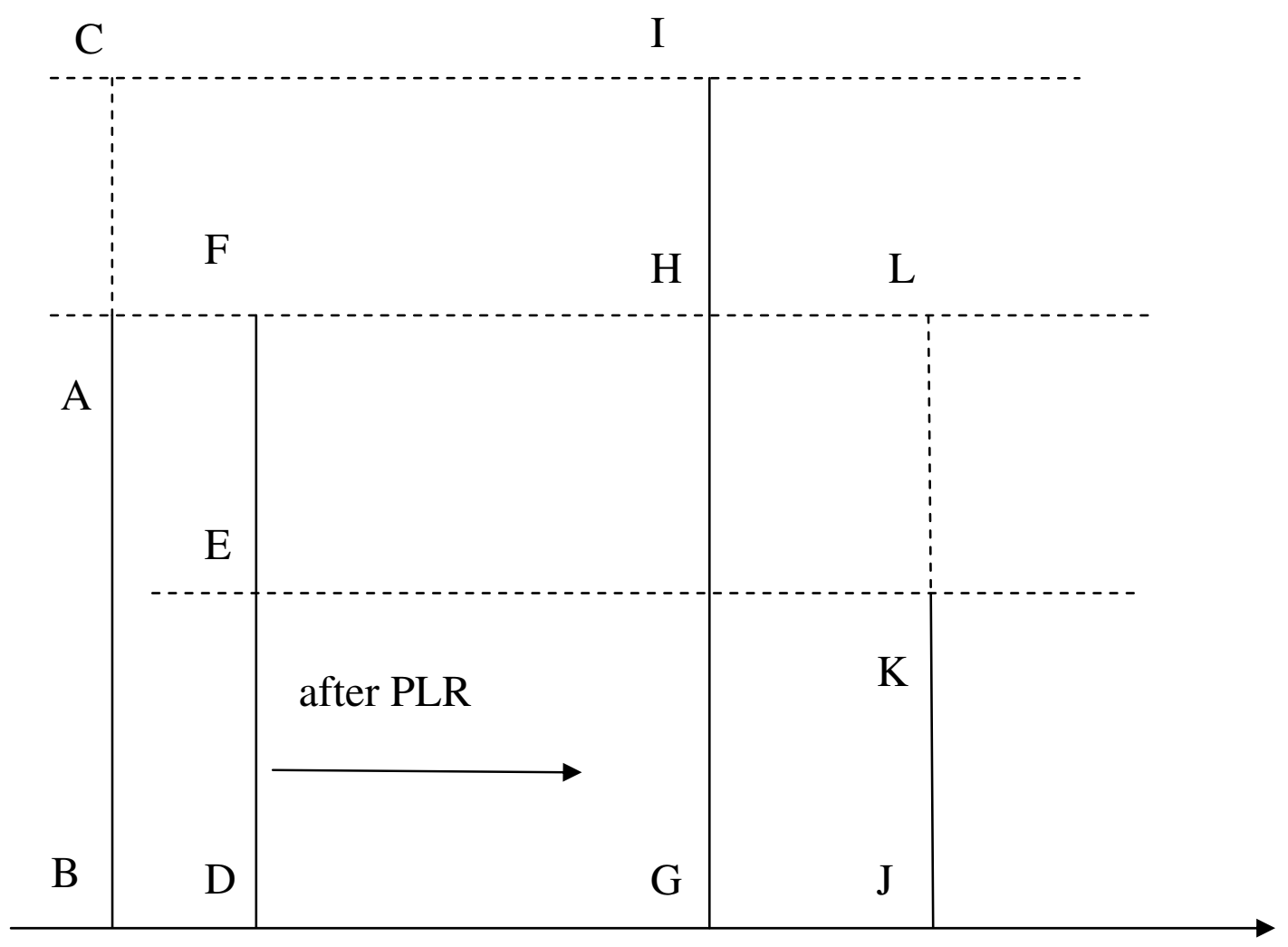


Appendix Table A Definition of Variables

\begin{tabular}{|c|c|}
\hline \multicolumn{2}{|l|}{ Dependent Variables } \\
\hline Rent In & Household rented in land is one, others zero \\
\hline Rent Out & Household rented out land is one, others zero \\
\hline Rent In Size & Area rented in where the unit is mu \\
\hline Rent Out Size & Area rented out where unit is $\mathrm{mu}$ \\
\hline \multicolumn{2}{|l|}{ Variables of Interest } \\
\hline FLR & Number of FLR experienced by the household since HRS \\
\hline PLR & Number of PLR experienced by the household since HRS \\
\hline \multicolumn{2}{|c|}{ Household Level Controls } \\
\hline Per Capita Arable Land & Arable land in the household divided by household size \\
\hline HH Head Age & Age of household head \\
\hline HH Head Age Square & Age square of household head \\
\hline Cadre Household & Dummy equals to one if more than one member in the household is cadre \\
\hline HH Head Education & Education level of household head \\
\hline Population $<16$ & Number of household members whose age is less that sixteen year old \\
\hline Population $16-60$ & Number of household members whose age is between 16 years old and 60 years old \\
\hline Population $>60$ & Number of household members whose age is more than 60 years old \\
\hline Female Ratio & Number of females divided by number males in the household \\
\hline Share of Off-farm Workers & Number of household members doing off-farm work divided by household size \\
\hline Agricultural Tax & Log of agricultural tax paid by the household in year 2002 \\
\hline Non-farm Assets & Total value of houses, transportation instruments, small business assets and so on \\
\hline Hogs & Log of number of hog in the household \\
\hline Cattles & Log of number of cattle in the household \\
\hline \multicolumn{2}{|l|}{ Village Level Controls } \\
\hline Distance to County & Distance of village to county centre in kilometer \\
\hline Sanction & Dummy equals to one if sanction is required for households who want to rent in or rent out land \\
\hline Rent & Village average value of rent for households who participate in land rental market \\
\hline
\end{tabular}

